Portland State University

PDXScholar

$11-21-1979$

\title{
Changes in Populations of Soil Acari During the First Year After Clearcutting
}

Sue Ellen Orlaske

Portland State University

Follow this and additional works at: https://pdxscholar.library.pdx.edu/open_access_etds

Part of the Agricultural Science Commons, and the Forest Sciences Commons

Let us know how access to this document benefits you.

\section{Recommended Citation}

Orlaske, Sue Ellen, "Changes in Populations of Soil Acari During the First Year After Clearcutting" (1979). Dissertations and Theses. Paper 2901.

https://doi.org/10.15760/etd.2897

This Thesis is brought to you for free and open access. It has been accepted for inclusion in Dissertations and Theses by an authorized administrator of PDXScholar. Please contact us if we can make this document more accessible: pdxscholar@pdx.edu. 
AN ABSTRACT OF THE THESIS OF Sue Ellen Orlaske for the Master of Science in Biology presented November 21, 1979.

Title: Changes in Populations of Soil Acari During the First Year After Clearcutting.

APPROVED BY MEMBERS OF THE THESIS COMMITTEE;
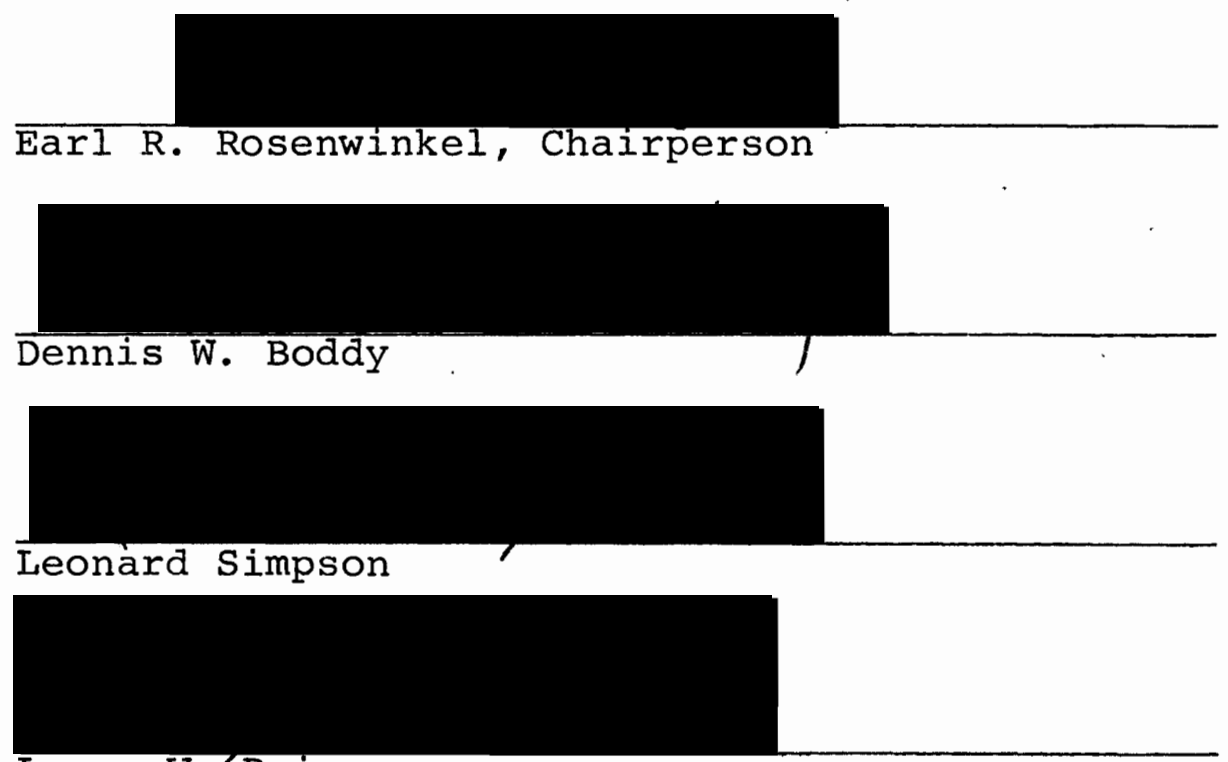

Larry W./Price

Soil samples taken from a clearcut and adjacent uncut site of a Douglas Fir and Western Hemlock old growth forest in the Cascade Range of southern Washington showed greatly reduced adult and juvenile population densities of macrophytophagous, microphytophagous, and predatory soil acari in the clearcut. These effects appeared to be due to high lethal summer litter temperatures and reduced pore spaces 
due to scarification. Also, the number of species of acari in the clearcut was lower than in the control after clearcutting. 
CHANGES IN POPULATIONS OF SOIL ACARI

DURING THE FIRST YEAR AFTER CLEARCUTTING

by

Sue E. Orlaske

A thesis submitted in partial fulfillment of the requirements for the degree of

\author{
MASTERS OF SCIENCE \\ in \\ BIOLOGY
}

Portland State University

1979 
TO THE OFFICE OF GRADUATE STUDIES AND RESEARCH:

The members of the Committee approve, the thesis of Sue Ellen Orlaske presented November 21, 1979.
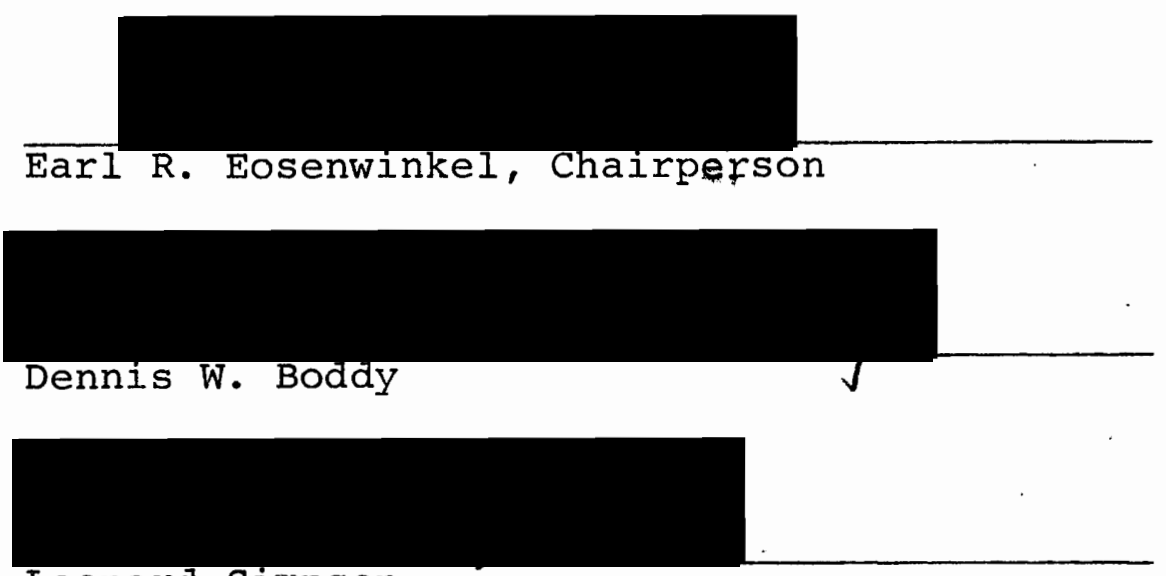

Leonard Simpson

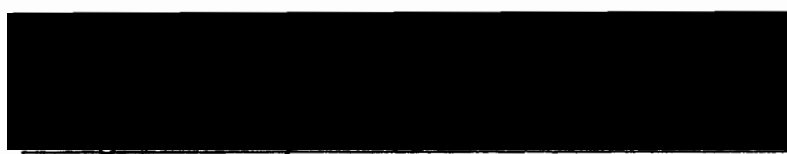

Larry W. Ppice

APPROVED :

W. Herman Taylor, Head, Degartment of Biology

Stanley E. Răuch, Dean of Graduate Studies and Research 


\section{ACKNOWLEDGMENTS}

I would like to extend thanks to Dr. Earl Rosenwinkel, my advisor, and Dr. Ellen Benedict for their help and criticism; Weyerhaeuser Corporation for providing me with a site; Mr. Robert Gooding, Kalama District Forest Manager, Weyerhaeuser Corporation, for his unending assistance and patience; Drs. Roy Norton and w. Calvin Welbourn for identification of my acari specimens; Mr. Rod Crawford for identification of my araneida specimens; Dr. Richard Forbes for providing me with laboratory space; Dr. Quentin D. Clarkson for assistance with statistical analyses; Drs. David Cook and Gerald Krantz for introducing me to the acari; and Ms. Esther Gruber for her contagious enthusiasm. I would also like to give special recognition and appreciation to my field assistants: Ellen Benedict, Michael Neiswonger, Kathy Orlaske, Earl Rosenwinkel, and D. Mitchell Wolgamott. 
TABLE OF CONTENTS

PAGE

ACKNOWLEDGMENTS .............................. ii

LIST OF TABLES ................... . . . . . $v$

LIST OF FIGURES .................... . . . . vi

INTRODUCTION . . . . . . . . . . . . . . . . . 1

Soil Microarthropods . . . . . . . . . . . . . 1

Effects of Clearcutting on Soil Microarthropods . . . . . 4

Purpose of Study ................. 6

MATERTALS AND METHODS ......................... 7

Site Description ... . . . . . . . . . . 7

Sampling Procedure ................ 9

RESULTS AND DISCUSSION . . . . . . . . . . . . . . 12

Similarity of Species Composition . . . . . . . . 12

Macrophytophagous Soil Acari .............. 13

Microphytophagous Soil Acari .............. 17

Panphytophagous Soil Acari . . . . . . . . . . . 18

Predatory Soil Acari . .............. . 19

Vertical Migration ............... . . . 25

Soil Compaction and Scarification . . . . . . . . 25

Temperature ................. . . 27

Moisture ................. . . 31

CONCLUSIONS ................................... 34

BIBLIOGRAPHY ....................... 37

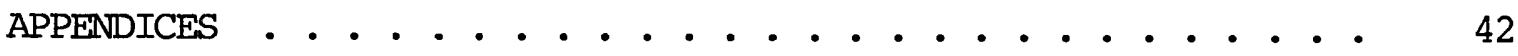

Habitat Data Sheet . . . . . . . . . . . . 42

Classification of Acari, Opiliones, and Araneida ...... 43

Tabulation of Data . . . . . . . . . . . 47

United States Weather Bureau Data . . . . . . . 58 


\section{IIST OF TABIES}

I Level of Significance of Density Differences of the

Life Stages of Parholaspella spatulata 
LIST OF FIGURES

FIGURE

PAGE

1. Map of site location ............. . . 8

2. Illustration of plot and numbering system used for sampling 10

3. Sørensen's Quotient of Similarity applied to the control and clearcut sites for each sample month . . . . . .

4. The number of species unique to each site on the different sampling days ...............

5. Changes in density of four genera of macrophytophagous ptyctiminid mites during the first year after clearcutting

6. Ptyctiminid mites mean clearcut density as percent of control ...................

7. Changes in density of the macrophytophagous genus Hermanniella during the first year after clearcutting . . .

8. Changes in density of the microphytophagous gamasid genus Trachytes during the first year after clearcutting . . .

9. Trachytes sp. mean clearcut density as percent of control .

10. Changes in density of the predatory actinedid genus Nicoletiella during the first year after clearcutting . . .

11. Changes in density of the predatory gamasid mite Parholaspella spatulata Krantz during the first year after clearcutting .................

12. Changes in mean control densities of nymph and adult Parholaspella spatulata during the first year after clearcutting ..................

13. Changes in mean clearcut densities of adult and nymph Parholaspella spatulata during the first year after clearcutting ...................

14. Changes in density of the predatory gamasid genus Gamasellus during the first year after clearcutting . . . . 
vii

FIGURE

PAGE

15. Changes in mean control densities of adult and nymphal Gamasellus during the first year after clearcutting . . .

16. Changes in mean clearcut densities of adult and nymphal Gamasellus during the first year after clearcutting . . .

17. Mean temperatures in the controls and clearcuts in the four sampling months following clearcutting ......... 
INTRODUCTION

Clearcutting, a widely-used practice in Europe and North America, is considered to be the most economically expedient method of harvesting large stands of timber, both for efficiency in harvesting and in reforestation (Smith 1962). The practice has been criticized not only for esthetic reasons but for its effects on watersheds and wildlife. Recently several authors have suggested that clearcutting results in nutrient depletion in soils (Moore and Norris 1974, Vitousek et al 1979), disturbance of soil biota food webs and consequent destruction of soil-building processes. (Bollen 1974, Mitchell and Sartwell 1974, Moore and Norris 1974, Szujecki 1971, 1972), and increases in numbers and densities of pest species (Francke-Grosmann 1963).

Soil Microarthropods

Wallwork (1970) defines soil animals as those which live in the soil on a permanent or temporary basis. The most numerous and diverse of these are represented by the arthropods: Pseudoscorpionida, Araneida, Opiliones, Acari, Isopoda, Insecta (larvae and adults), Chilopoda, Symphyla, Diplopoda, and Pauropoda. The Annelida and Nematoda are also abundant. These organisms may be herbivores, fungi- 
vores, or carnivores.

Forest soil animals are usually dependent on detritus food chains. The source of their nutrients is litter from vegetation or the fungi and bacteria which utilize the litter. Larger organisms, such as lumbricid annelids, generalIy play a mechánical role in litter breakdown, while smaller animals are considered to be regulators of the decomposition of these residues (Crossley 1977b, Edwards and Heath 1963, Ghilarov 1963, 1971). This regulation may be accomplished directly by feeding on the litter and associated microflora (Engelmann 1961, Gist and Crossley 1975), or indirectly by mixing the soil, enriching the soil with their feces, eliminating mycostasis and bacteriostasis (MacFadyen 1963), distributing fungal spores to favorable sites for germination (Witkamp 1960), enhancing microbial growth by browsing of senescent colonies (Hinshelwood 1951) and by exposing new material (Engelmann 1961), providing a substrate for microflora with their feces (McBrayer 1973), - inoculating litter with microbes and microbial spores (Crossley 1977b, Engelmann 1961, Ghilarov 1963), and fragmenting the litter material (Gray and Wililiams 1971, Kurcheva 1960, Witkamp and Crossley 1966). As such, soil animals have a significant role in soil development and nutrient cycling (Cornaby 1977, Crossley 1977a, MacFadyen 1961).

Soils under coniferous forests are acidic in nature and are therefore favorable for the proliferation of soil 
fungi (Griffin 1972). Acid conditions, however, are unfavorable for many soil animals, such as lumbricid annelids, diplopods, and isopods. Therefore the dominant groups of microarthropods which occur in coniferous soils are fungivorous mites of the suborder oribatida and fungivorous insects of the order Collembola (Huhta et al 1967, Krantz 1978, Wallwork 1976).

Soil microarthropods are horizontally distributed in the soil in a. contagious way (Hartenstein 1961, MacFadyen 1962, Mitchell 1978). Microhabitat appears to be important in this 'clumping'effect, but the specifics of this are not clearly understood, Even 'pure' woodland stands may show local variations in biological characteristics of the forest floor which may influence distribution patterns (Cornaby 1977, MacFadyen 1968, Wallwork 1976). Mitchell (1978) indicates that horizontal distribution varies with species among oribatid mites, and that distribution is positivelycorrelated with moisture for those mites inhabiting soil layers below $2.5 \mathrm{~cm}$, and negatively. or not correlated for those mites inhabiting organic layers above $2.5 \mathrm{~cm}$. Hartenstein (1961) indicates that food availability causes aggregation of oribatids in the laboratory, and predatory mites of the suborder Gamasida are attracted to these sites indirectly.

Microarthropods are also vertically distributed in the soil. Some are mainly litter inhabitants, some are fer- 
mentation layer inhabitants, and some occupy the humus horizon. Immatures appear to inhabit deeper horizons (Mitchell 1978). Vertical migrations may be seasonal or diurnal, and may be correlated with soil moisture (Madge 1964, Mitchell 1978), temperature (Madge 1965, Wallwork 1959, 1960), available food supplies (Wallwork 1958, 1960), and carbon dioxide levels (MacFadyen 1968).

Effects of Clearcutting on Soil Microarthropods

The effects of clearcutting on soil microarthropods have not been well-covered in the literature. Few major studies have been made, and fewer still analyze density and diversity changes of populations. Most studies group all mites, all spiders, etc. together as if the groups perform identical roles in the soil community (Cornaby 1977). The results have been inconclusive.

Huhta et al $(1967,1969)$ conducted a major study of the effects of forest management on soil arthropods, nematades, and annelids inhabiting coniferous forest soil. They compared several sites in Finland which had been uncut (controls), clearcut one year previously, slash-burned, etc. The sites, although not adjacent, were chosen for similarity in vegetation. They found that oribatid mites increased in density during the first year after clearcutting, but not significantly. They attributed this effect to the increased moisture resulting from slash accumulation during clearcut- 
ting, rather than to food availability. The densities of oribatid mites dropped significantly below the densities in the control plots after the second year, and remained low. 'Other Acarina' in the study, considered as a group, followed a similar pattern. Huhta et al (1967) concluded that the taxa of Acari are too heterogenous to serve as a basis for conclusions. They noted however that the same species appeared to dominate in the controls and clearcuts, but the number of species increased due to influx of different ones into the clearcut area. Moritz (1965) found that dominant species of oribatid mites change after clearcutting, and Szujecki (1971, 1972) noted a change of staphylinid beetles from specific feeders to eurytopic species after clearcutting.

Vlug and Borden (1973) examined a site in British Columbia one year after clearcutting, and emphasized vertical migration through the first $10 \mathrm{~cm}$ of soil. Density decrased in logged areas in all four levels of soil studied. The family Oribatulidae of oribatid mites showed the greatest increase in abundance, from $3.7 \%$ in the controls to 17.7\% in the clearcuts. Correlations of densities with physical parameters (moisture, temperature, and $\mathrm{pH}$ ) were not significant, and they indicated that such factors as food supply may be important.

Huhta (1976) examined numbers, biomass, and community respiration of various soil invertebrates in clearcuts 
3-13 years of age. Only enchytraeid annelids showed a distinctly greater biomass than controls, and only in sites 8-13 years old. The total biomass increased strongly after clearcutting, mainly due to lumbricid and enchytraeid population increases. The total biomass of arthropods did not exceed controls at any stage. Increases in community respiration followed that of biomass, but was more evident. This was attributed to the higher average temperatures in the soils of clearcut areas; again, enchytraeids made the largest contribution. Huhta concluded that the temporary increase was due to slash decomposition at the time of clearcutting, but that a very limited number of species appear to use most of the extra resources. As the organic matter is consumed, the animal biomass diminishes, and microarthropods evidently flourish at an earlier stage of decomposition than the enchytraeids.

\section{Purpose of Study}

Because mites play an important role in soil-formation processes, and subsequent nutrient release, representative macrophytophagous, microphytophagous, and predatory genera or species were studied in a clearcut area. The population densities were followed during the first year after logging in adjacent sites to determine if the practice of clearcutting has an effect on them, and, if so, to determine what type of population changes occur, and why. 


\section{MATERIALS AND METHODS}

Site Description

Soil-litter samples were taken from a northwest-facing ridge on the Weyerhaeuser st. Helens Tree Farm in the Kalama River district of washington, Cowlitz County, T7N-R3E, Section 13. See Figure 1. The tree farm is in the Tsuga heterophylla zone of the mesic temperate conferous forests (Franklin and Dyrness 1973). The study area is an oldgrowth stand which includes Douglas Fir, Pseudotsuga menziesii (Mirb.) Franco; Western Hemlock, Tsuga heterophylla (Raf.) Sarg.; Pacific Silver Fir, Abies amabilis (Dougl.) Forbes; Western White Pine, Pinus monticola Dougl. ex D. Don; Vine Maple, Acer circinatum Pursh; Salal, Gaultheria shallon Pursh; Red Huckleberry, Vaccinium parvifolium Smith; Blue Huckleberry, Vaccinium membranaceum Dougl. ex. Hook.; Oregon Grape, Berberis nervosa Pursh; Common Beargrass, Xerophyllum tenax Nutt., and numerous lichens and mosses. The ridge has a slope of $20 \%$. The soil belongs to the Yale series, which are deep, medium-textured, well-drained reddish-brown Laterites developed from deep deposits of volcanic ash and pumice. The 50-year site index is $120^{\prime}$ for Douglas Fir and 110' for Western Hemlock (Duncan and Steinbrenner 1973). Elevation is $731.5 \mathrm{~m}$. Mean annual precipitation is $250 \mathrm{~cm}$; mean annual temperature is 8-9 degrees 


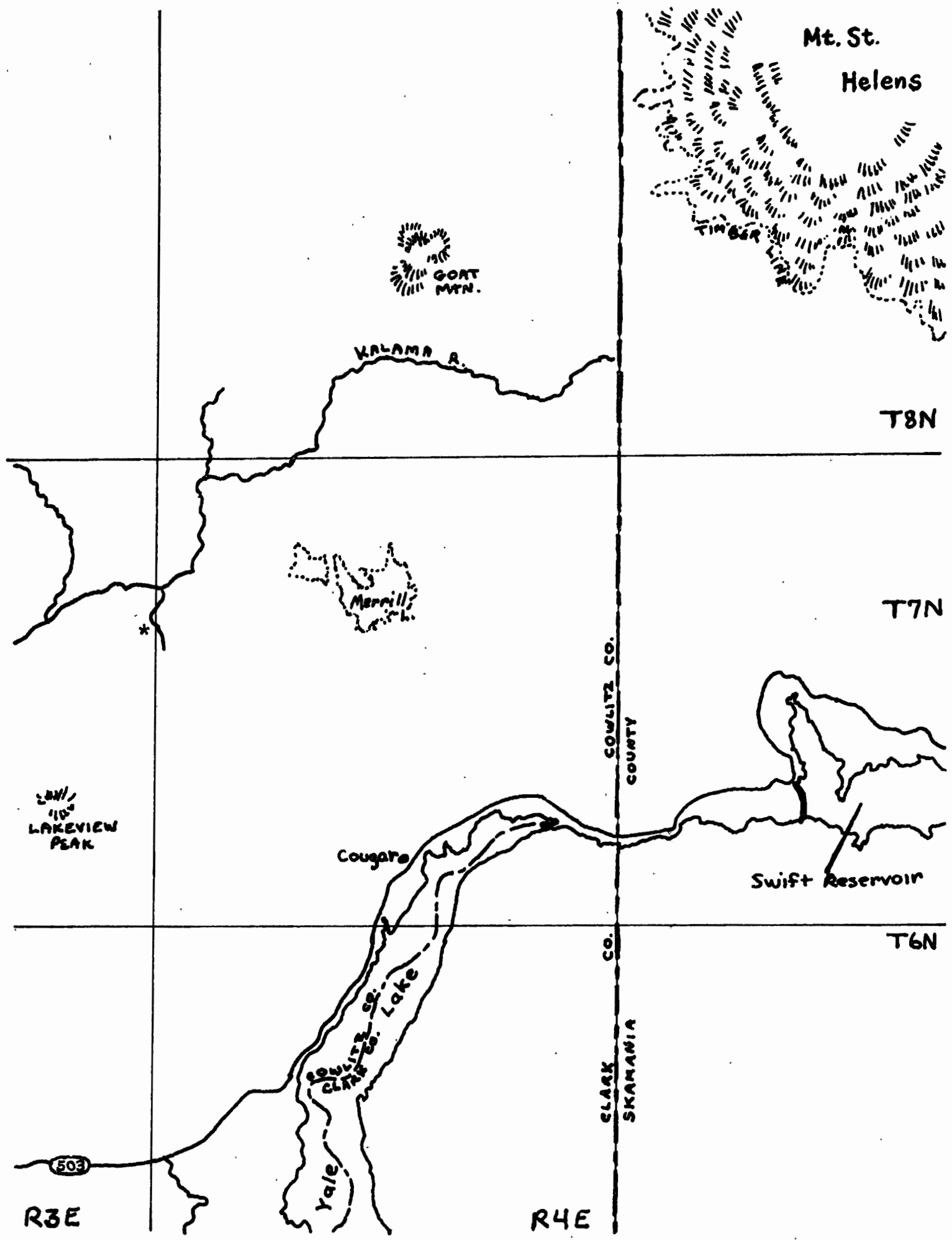

Figure 1. Map of site location; asterisk (*) indicates site. 
Centigrade, with a January mean minimum temperature of -2.5 degrees Centigrade, and a July mean maximum temperature of 24.5 degrees Centigrade (Franklin and Dyrness 1973).

On April 15, 1978 a study area was selected on the ridge where a cut line had already been surveyed and marked by the Weyerhaeuser Corporation. The cut line ran northeast to southwest. The forest to the southeast of the line was not to be logged, and was used as the control site. The forest to the northwest of the line was part of a 95-acre unit logged by Weyerhaeuser between April 17 and May 20, 1978, and was used as the experimental site. The unit was not sprayed with herbicides, since Red Alder, Alnus rubra Borg., and other plant competitors of seedling Douglas Fir were absent, and since shrubs such as Vaccinium sp. shade soils. The unit was not slash-burned since little slash was left after logging ( $R$. Gooding, pers. comm.). The 95-acre unit had an average yield of 150 cunits per acre; however, the ridge averaged only 85 cunits per acre. Most of the timber from the ridge was used for pulp.

\section{Sampling Procedure}

Samples were collected April 16 (pre-logging), May 20, July 29, October 7, 1978, and March 29, 1979, approximately $35 \mathrm{~m}$ southeast of the cut line in the unlogged site, and approximately $20 \mathrm{~m}$ northwest of the cut line in the logged site. Each site was divided into four plots, and'each plot 
was marked into 28 stations spaced at $3.33 \mathrm{~m}$ intervals (Figure 2). On each sampling day, litter and soil were collected from four randomly-sampled stations per plot. Each soil-litter sample measured $13 \mathrm{~cm}$ deep and $10 \mathrm{~cm}$ in diameter, and was trowel-collected and placed in an individual plastic bag. Each sample bag was numbered consecutively and habitat data (Appendix A) were recorded for each. Two of the four samples were randomly-selected from each plot to be divided into upper and lower core halves; these were bagged and numbered separately.

In each plot, temperatures were measured using a Yellow Springs Tele-Thermometer (Model 46) attached to thermistors placed $61 \mathrm{~cm}$ above the soil surface, $1 \mathrm{~cm}$ below the

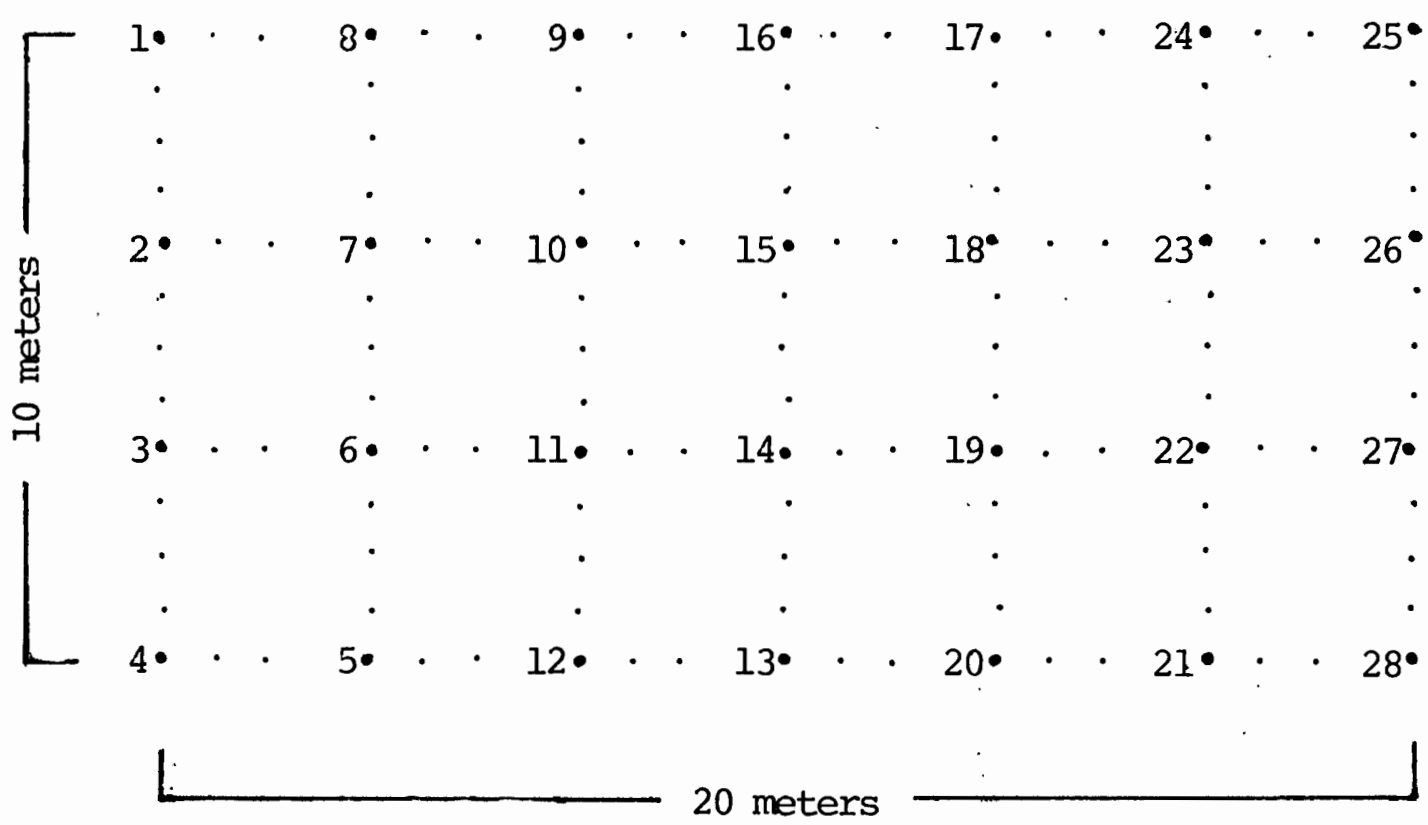

Figure 2. Illustration of plot and numbering system used for sampling; four plots were designated in both the control and in the clearcut areas. 
soil surface (referred to as 'surface' or 'litter' temperature in the text), and $13 \mathrm{~cm}$ below the soil surface.

Soil moisture readings were taken only in october and March using a Soiltest MC300A Moisture meter.

Soil organisms were extracted from each sample into $70 \%$ ethyl alcohol using individual Berlese funnels equipped with 25-watt light bulbs as described by Wallwork (1970). The samples were sorted and statistically analyzed as follows: some groups of mites were analyzed for relative abundance, using the negative binomial transformation

$$
\mathrm{x}^{\prime}=\log _{10}(\mathrm{x}+\mathrm{k})
$$

were $\mathrm{X}$ is the density of the sample, and $\mathrm{k}$ is equal to one (Anscombe 1949, Berthet and Gerard 1965, Gerard and Berthet 1966); other groups of mites were sorted for frequency of occurrence using the angular transformation

$$
x^{\prime}=\arcsin \sqrt{\bar{p}}
$$

where $\mathrm{p}$ is the proportion of samples per site in which the group occurs (Sokal and Rohlf 1969). The negative binomial transformation and the angular transformation allow analysis of variance to be utilized on contagious, or clumped, population distributions. 
Similarity of Species Composition

Figure 3 shows the percent similarity of species composition in the control and clearcut sites using s $\varnothing$ rensen's Quotient of Similarity

$$
\frac{Q}{S}=\frac{2 j}{(a+b)} \times 100
$$

where $j$ is the number of species common to both samples, a is the number of species recorded in the control, and $b$ is the number of species recorded in the clearcut. This quotient expresses $100 \%$ similarity when all species are common to both areas (Wallwork 1976, Sørensen 1948). Figure 4 com-

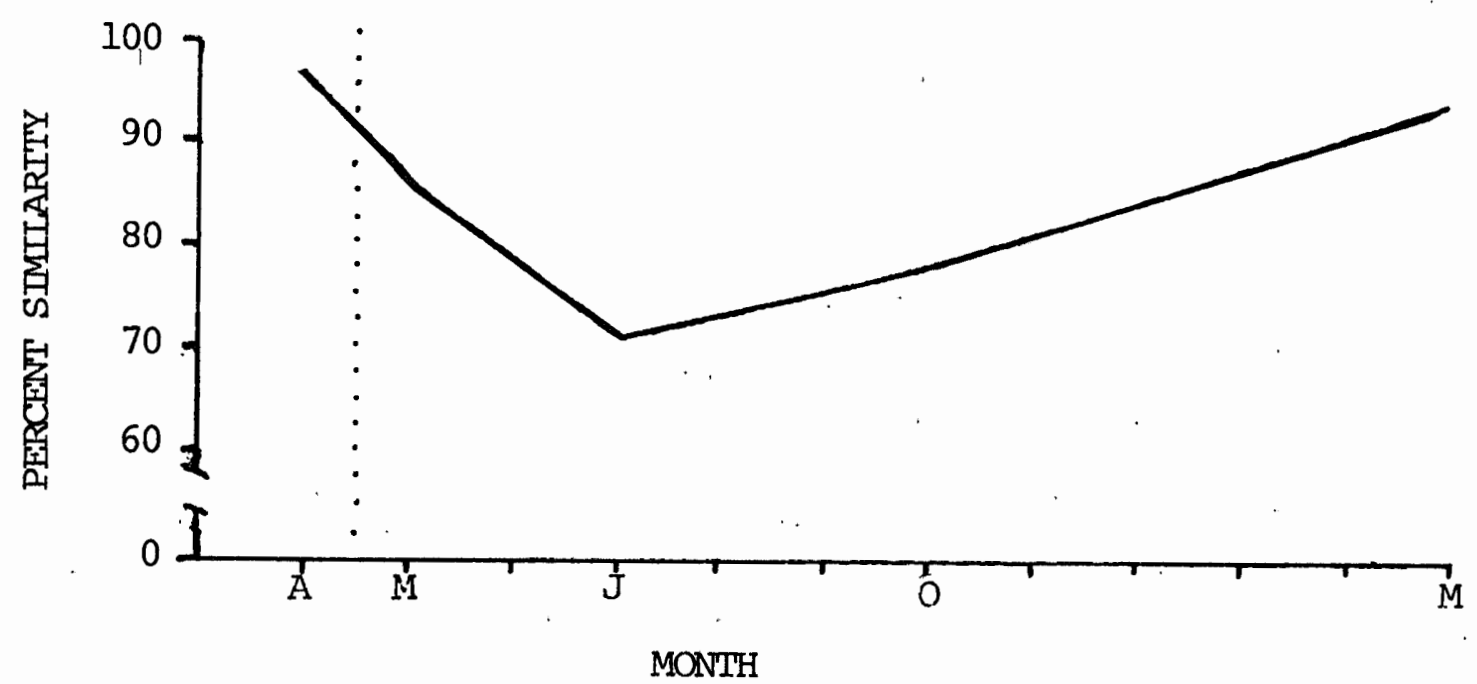

Figure 3. Sørensen's Quotient of Similarity applied to the control and clearcut sites for each sample month. See text for explanation. Dotted line indicates period of liearcut operation. 


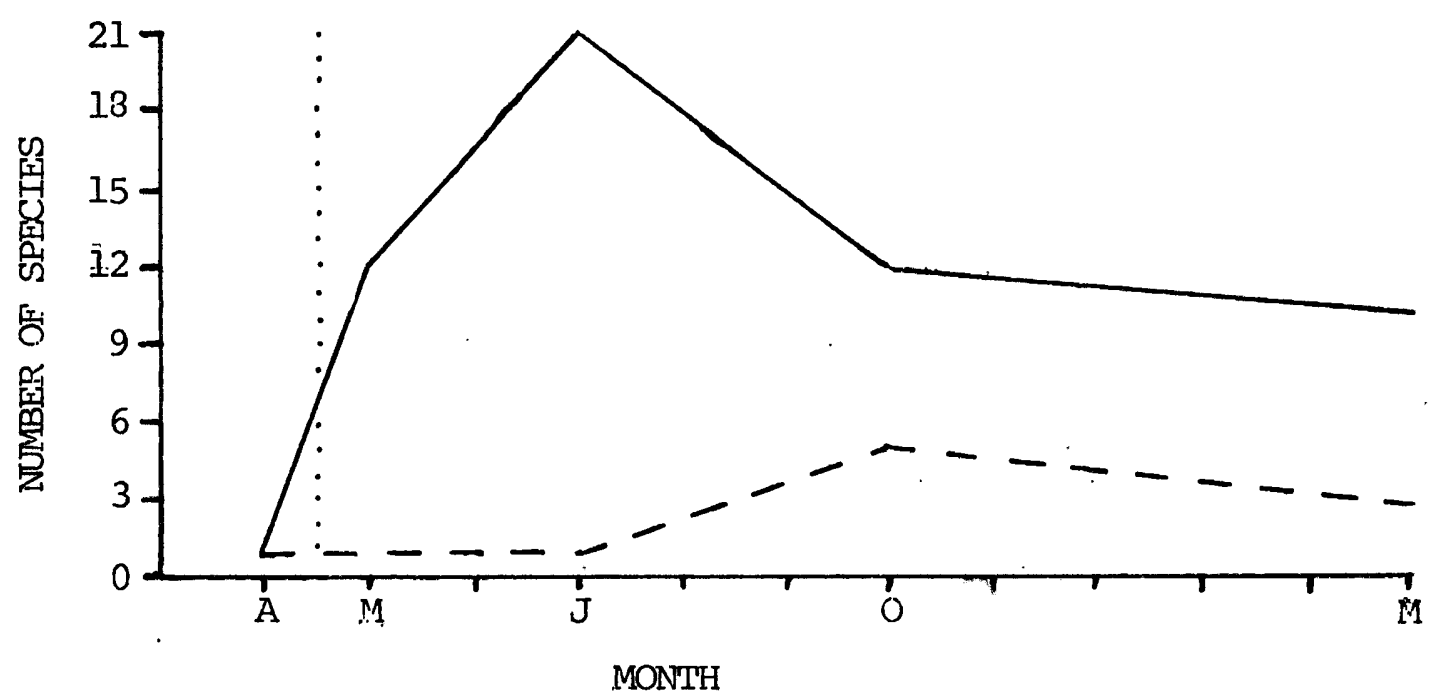

Figure 4. The number of species unique to each site on the different sampling days. Dotted line indicates period during which clearcutting occurred. Solid line represents control numbers; dashed line represents clearcut numbers.

pares the number of species unique to each site on the different sampling days. As the species composition becomes more similar, the lines are expected to converge to zero. After clearcutting, the control site supported a higher diversity of mites than did the clearcut site.

Appendix. B taxonomically lists identified species obtained from the samples during this study.

Macrophytophagous Soil Acari

Three ptyctiminid families of the oribatid supercohort Macropylides (Lower Oribatida), represented by the genera Oribotritia, Protoribotritia, Euphthiracarus, and Phthiracarus, were analyzed together, since they are thought to perform similar roles in the decomposition process as macro- 


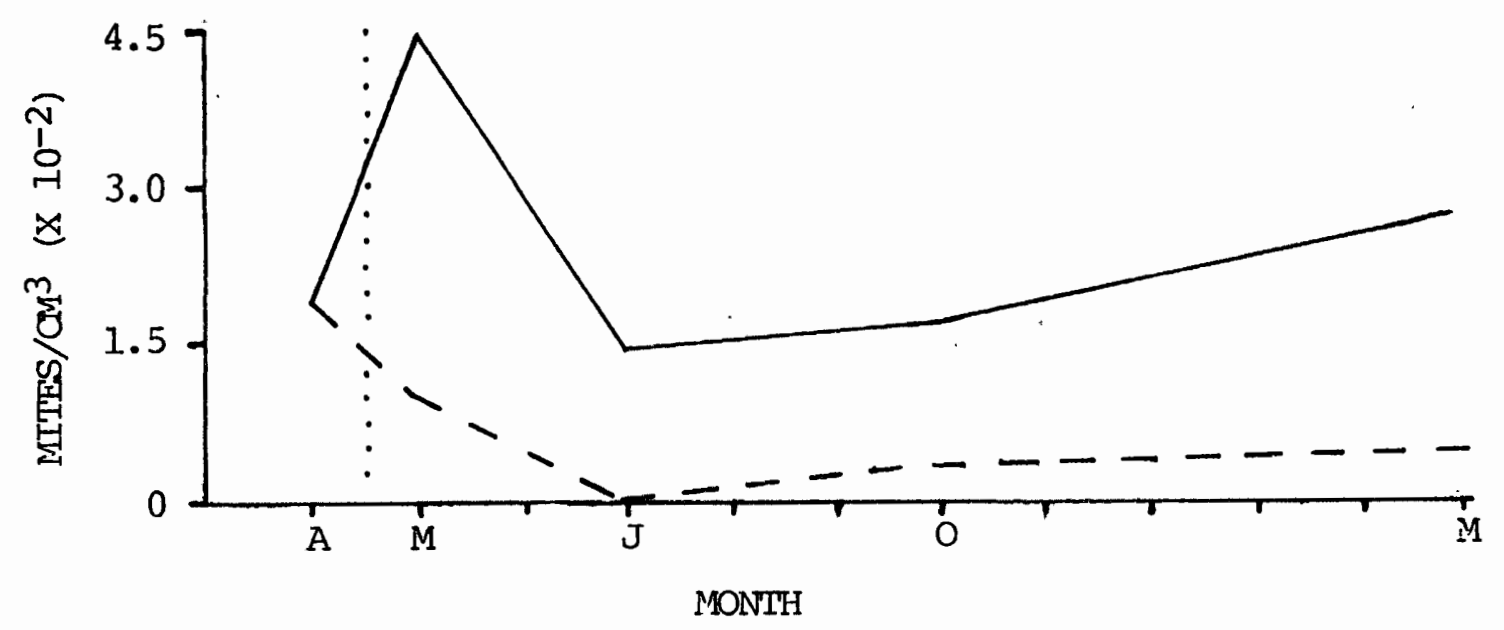

Figure 5. Changes in density of four genera of macrophytophagous ptyctiminid mites during the first year after clearcutting. Mean density of control (solid line) and clearcut (dashed line) shown. Vertical dotted line indicates period during which clearcutting occurred.

phytophages (Jacot 1939, Luxton 1972). There was a significant statistical difference $(\alpha=0.05)$ in densities between the control and clearcut sites after clearcutting, but no statistical difference among sampling days within treatments. Figure 5 illustrates the seasonal fluctuations of the control and clearcut during the first year after clearcutting. Although both populations have dropped dramaticalIy by July, the control recovers to the previous year's density by the following March, and the clearcut density remains low. Figure 6 shows the clearcut population as a percent of the control. By March of the following year the densities in the clearcut appear to have stabilized to about $18 \%$ of the control densities.

The oribatid genera Hermanniella, of the supercohort Brachypylides (Higher oribatida), is also thought to be a 


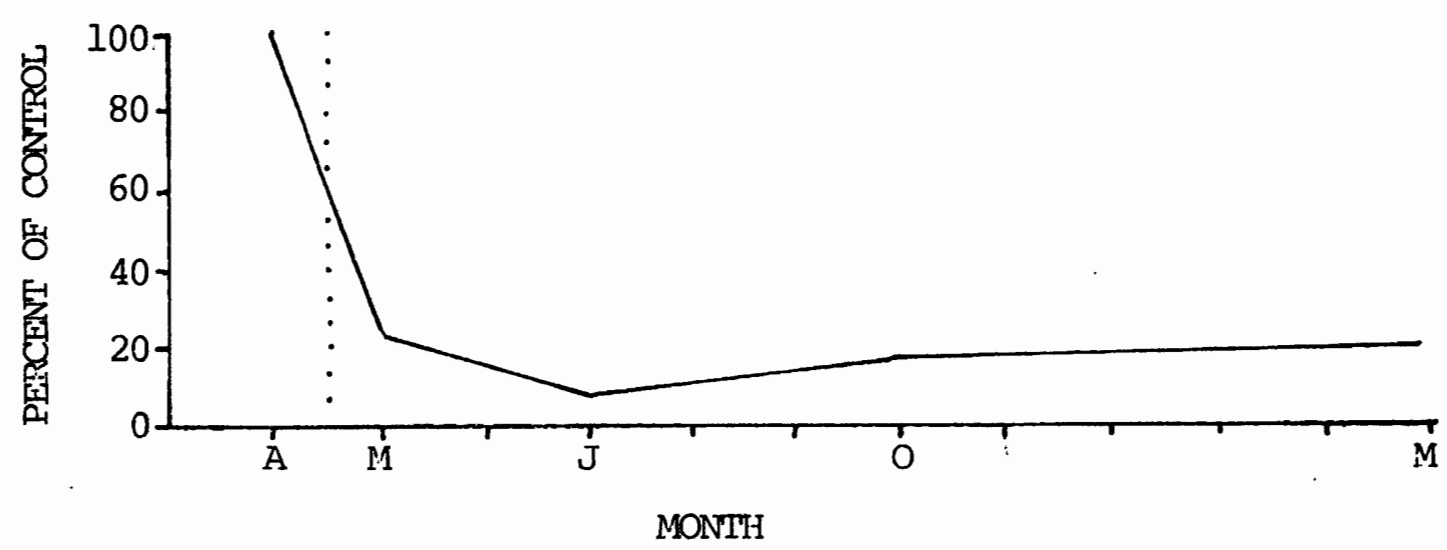

Figure 6. Ptyctiminid mites mean clearcut density as percent of control. Vertical dotted line indicates period during which clearcutting occurred.

macrophytophage (Luxton 1972). Figure 7 shows that the Hermanniella populations rose in both areas immediately after the clearcut occurred, and were not significantly different. In July, however, the populations decreased in both areas to significantly $(\alpha=0.05)$ different levels from each other. There was a recovery in October, but the clearcut populations remained below the control populations in March 1979.

The ptyctimid mites were immediately affected by clearcutting, and did not benefit from the newly-fallen litter from the felling operations. This is to be expected since macrophytophagous mites generally attack residues which have had distasteful polyphenols and tannins leached from them after a period of time (Wallwork 1976). In this case, the represented genera varied from relatively large mites (e.g. Oribotritia) to relatively smalf mites (e.g. 


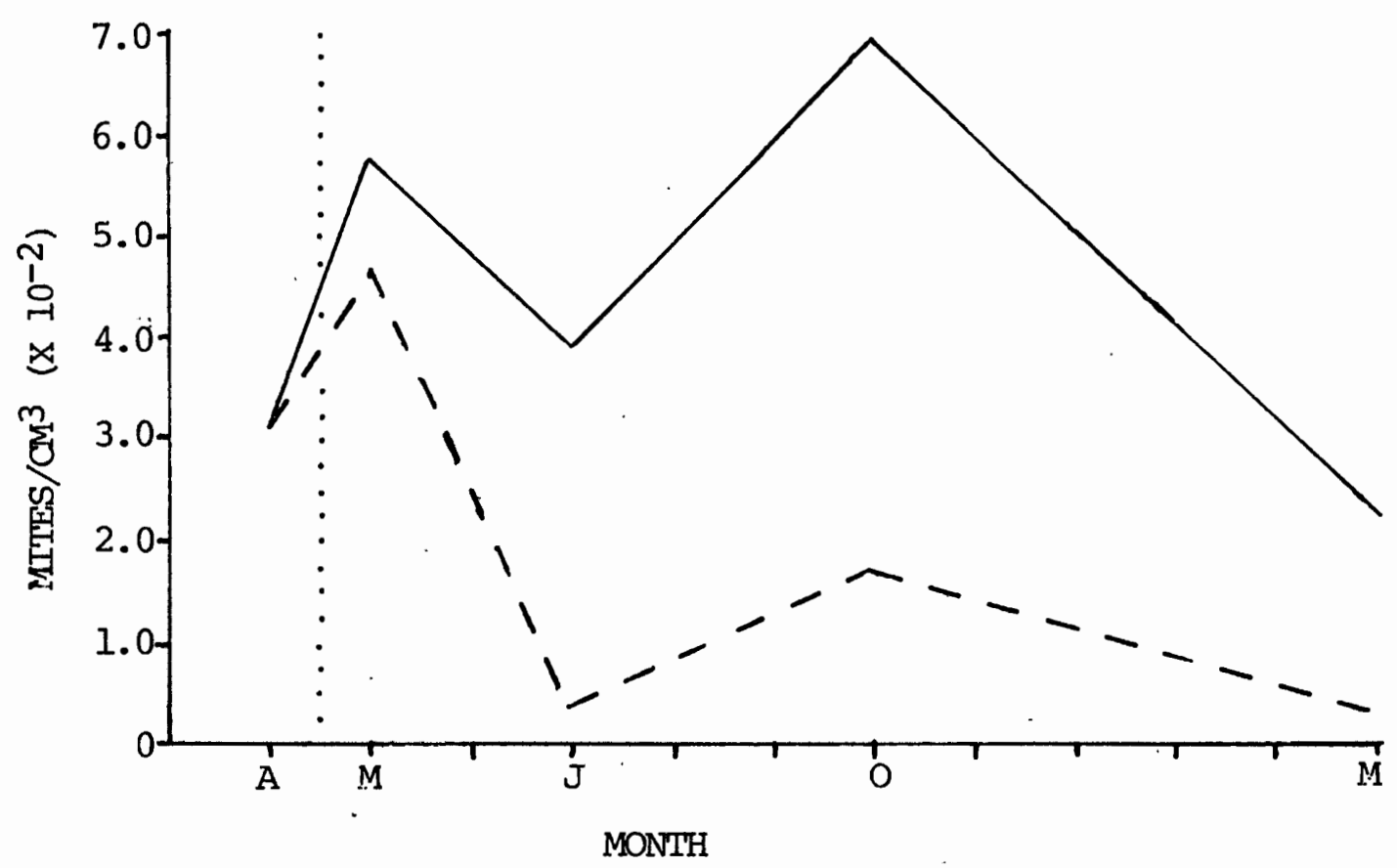

Figure 7. Changes in density of the macrophytophagous genus Hermanniella during the first year after clearcutting. Graph description as in Figure 5.

Protoribotritia) so the affects of pore space size could not readily be evaluated. However, the data for the mediumsized genus Hermanniella indicate that the residues deposited by the clearcutting operations may have benefitted the group temporarily by allowing relatively large numbers of overwintering individuals from previous months to survive in the residue habitat. As stated above, this effect did not last since the new litter could not provide a suitable food supply for these mites. In each case for macrophytophagous mites, the July low clearcut densities were not able to recover to control levels. 
Microphytophagous Soil Acari

The fungivorous gamasid mite Trachytes had significantly lower $(\alpha=0.01)$ densities in the clearcut than in the control after clearcutting. Figure 8 illustrates the seasonal fluctuations in the control and clearcut. Figure 9 shows the dramatic decline in clearcut densities as percent of the control. No Trachytes species were found in the July or March clearcut samples, and very few were found in October.

The genus Trachytes is a relatively large mite and probably inhabits the litter horizon of the soil, where pore spaces are large. Scarification of the soil during clearcutting operations, and increased temperatures in the upper layers, probabiy outweighed any benefits these mites

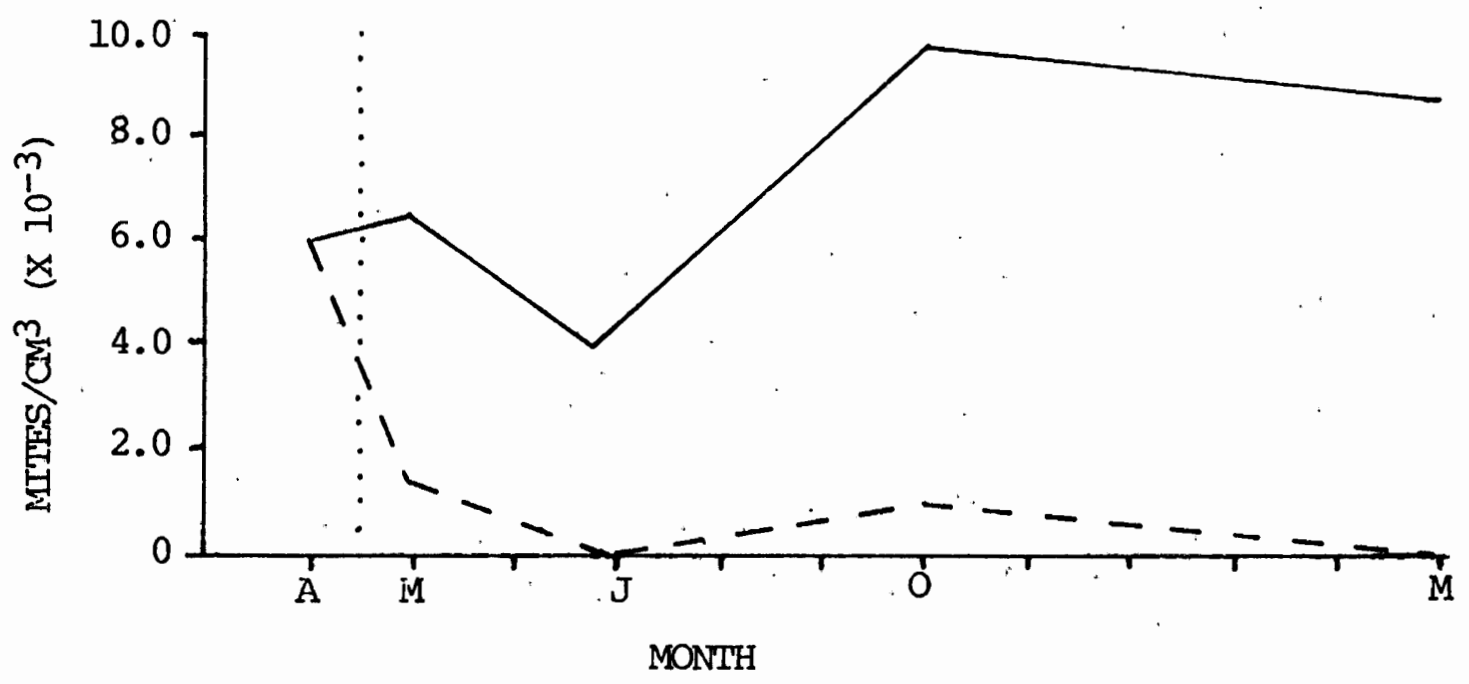

Figure 8. Changes in density of the microphytophagous gamasid genus Trachytes during the first year after elearcutting. Graph description as in Figure 5. 


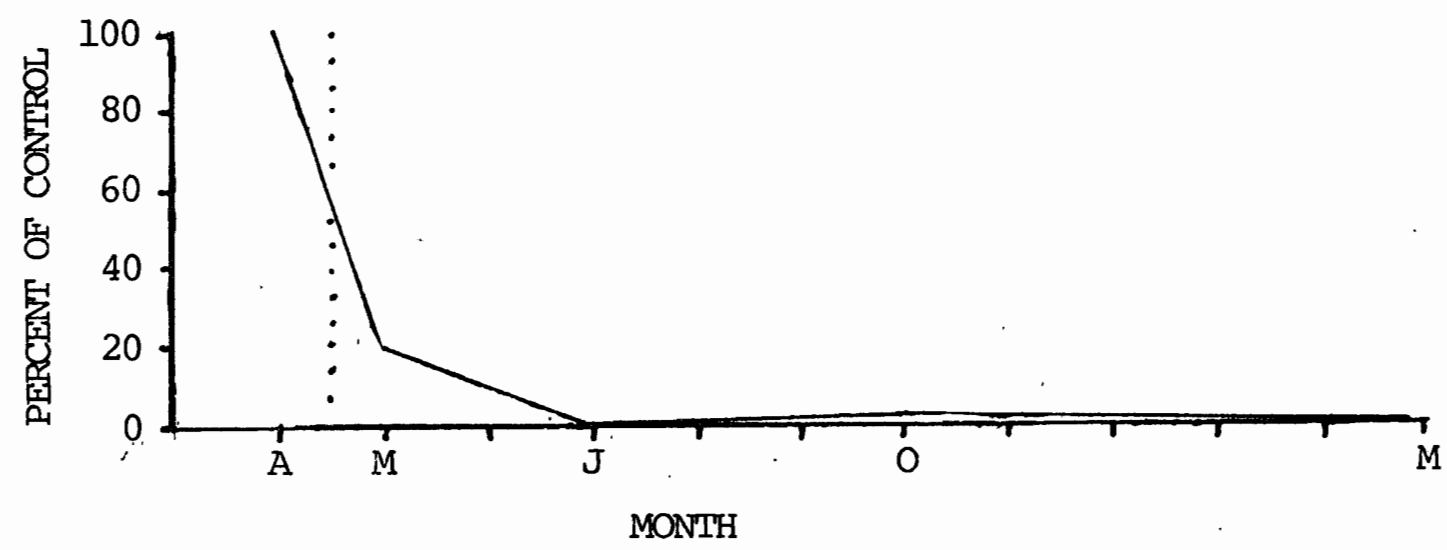

Figure 9. Trachytes sp. mean clearcut density as percent of control. Graph description as in Figure 6.

may have had from freshly-fallen litter and the microbial activity on it.

Panphytophagous Soil Acari

The generalist-feeder mite genus Nanhermannia showed a significantly lower $(\alpha=0.01)$ frequency of occurrence in the clearcut than in the control after clearcutting. The clearcut proportions in October 1978 and March 1979 were about $60 \%$ of the control proportions.

This mite is medium-sized and probably was able to avoid environmental stresses due to pore space sizes more easily than was Trachytes. Also, being a generalist, the food requirements of Nanhermannia are probably less demanding than those of specific feeders. 
Predatory Soil. Acari

The predatory actinedid mite genus Nicoletiella showed signficant differences between treatments $(\alpha=0.05)$ as well as among days within treatments $(\alpha=0.01)$. The control and clearcut densities both rose in May immediately after the logging operation, and plunged in July. However, Figure 10 indicates that the clearcut population did not recover in density by October as did the control.

The predatory gamasid species Parholaspella spatulata Krantz decreased in density in both controls and clearcuts over the year, but the density was significantly lower $(\alpha=0.01)$ in the clearcut than in the control sites. Figure 11 shows the mean densities for the first year. The nymphs and adults were separated and analyzed further. Table I shows the level of statistical significance of the

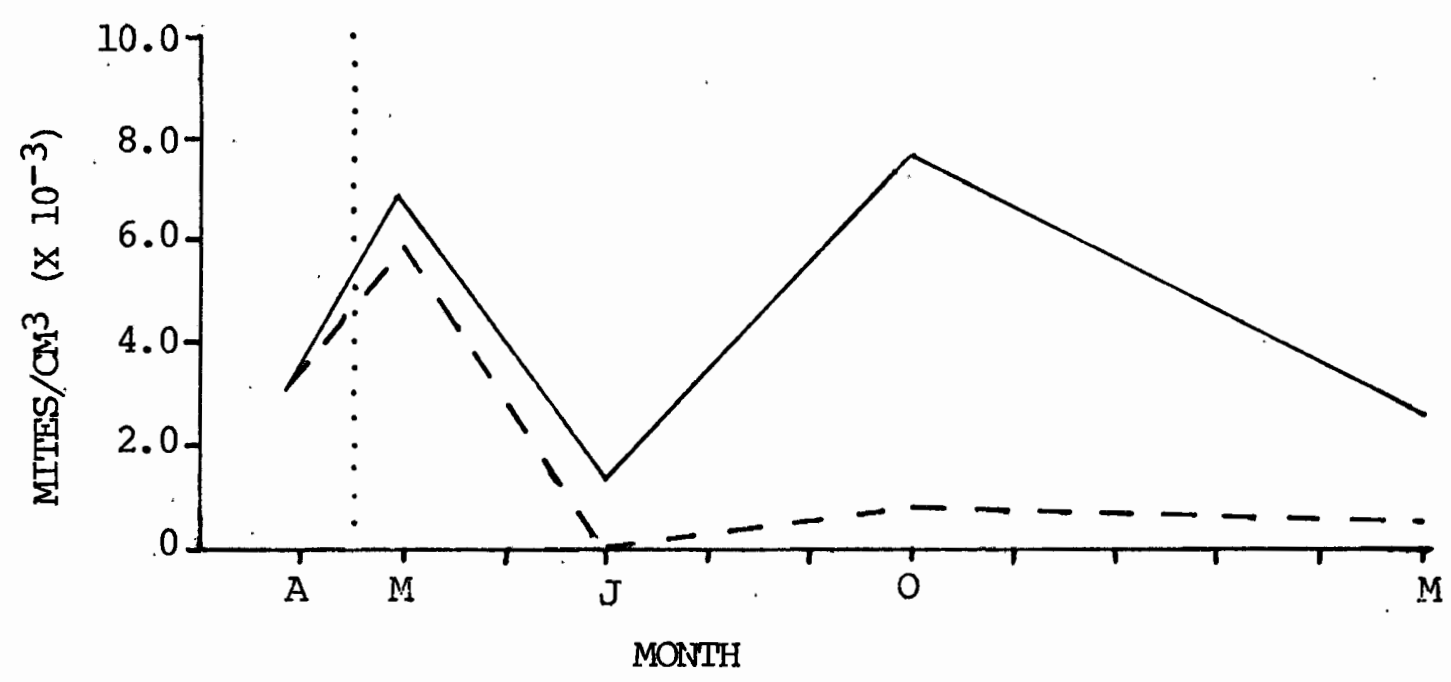

Figure 10. Changes in density of the predatory actinedid genus Nicoletiella during the first year after clearcutting. Graph description as in Figure 5. 


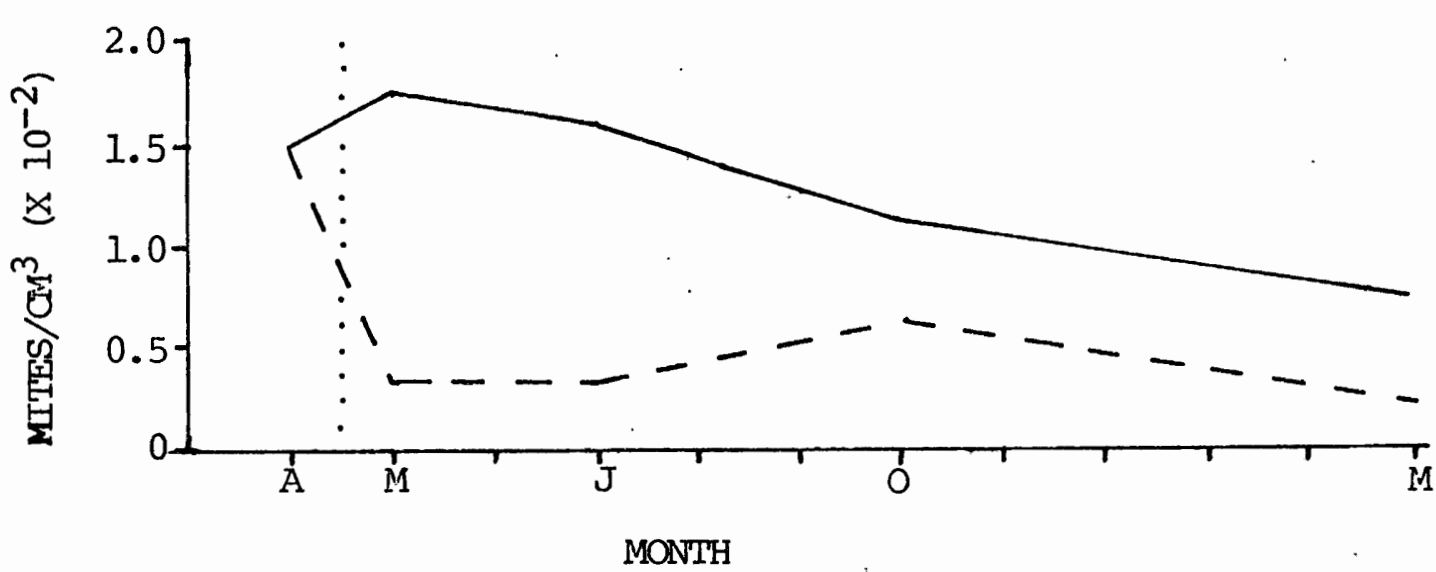

Figure 1l. Changes in density of the predatory gamasid mite Parholaspella spatulata Krantz during the first year after clearcutting. Graph description as in Figure 5.

results illustrated in Figures 11,12 , and 13 in which densities for the adults and nymphs are plotted.

Table I indicates that the nymphs were affected by the clearcut treatment during the year more than the adults . When densities of the adults and nymphs were plotted in the control and clearcut (Figures 12 and.13) adult densities in the control sites appeared to be recovering to the previous year's levels, after the summer seasonal decline,

\section{TABLE I}

LEVEL OF SIGNIFICANCE OF DENSITY DIFFERENCES OF THE LIFE STAGES OF PARHOLASPELIA SPATUIATA

$\begin{array}{llll} & \text { Between Control } & \text { Among Days } & \text { Among Sites } \\ \text { Stadia } & \text { and Clearcut } & \text { Within } & \text { Within } \\ & \text { Treatments } & \text { Treatments } & \text { Days }\end{array}$




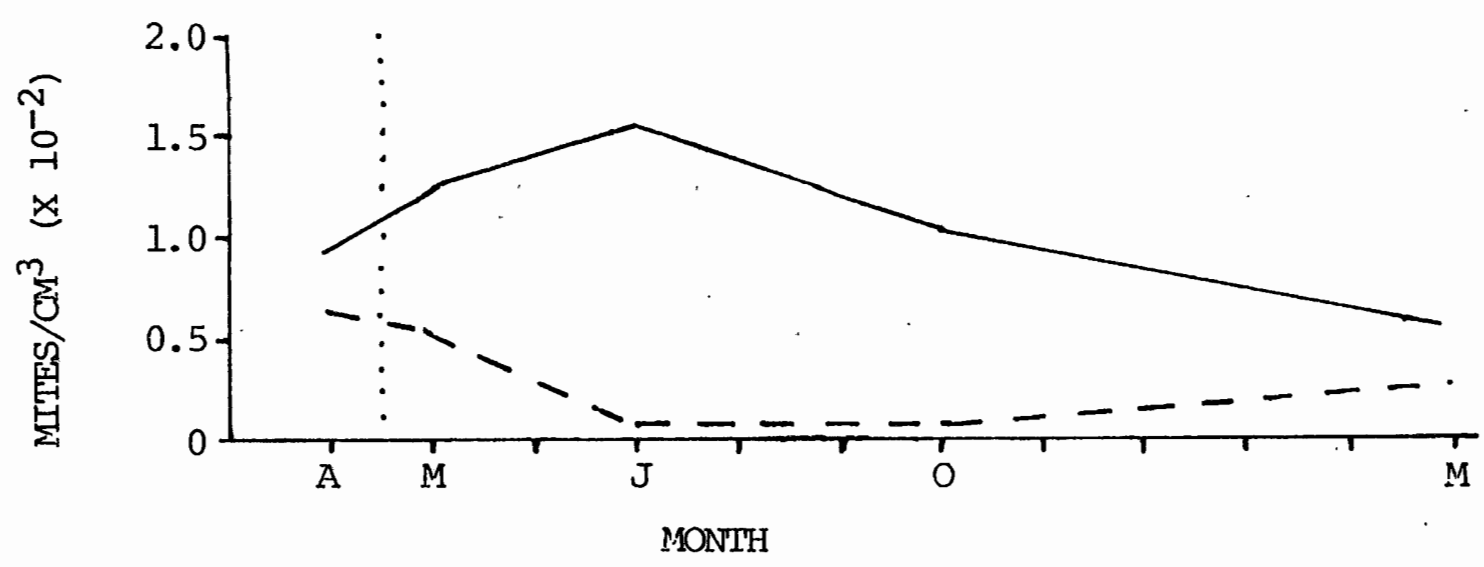

Figure 12. Changes in mean control densities of nymph (solid line) and adult (dashed line) Parholaspella spatulata during the first year after clearcutting. Vertical dotted line indicates period during which clearcutting occurred.

but in the clearcut they were not recovering. This indicates that in the clearcut, immatures did not develop to new adults between July and October as they did in the control. Nymph densities decreased in the control and clearcut both, but would be expected to decrease in densities as new adults developed from them, as occurs in the control sites. The

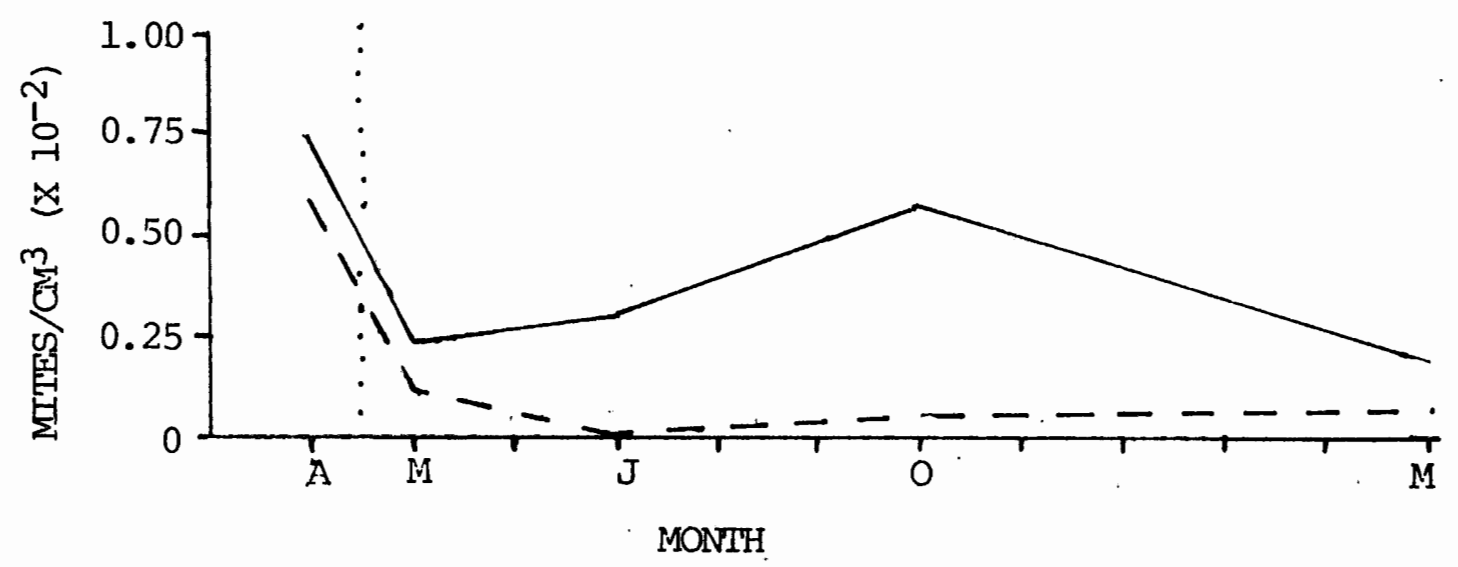

Figure 13. Changes in mean clearcut densities of adult and nymph Parholaspella spatulata during the first year after clearcutting. Graph description as in Figure 12. 
lack of recovery of adult densities in the clearcut may be due to lack of prey availability, to increased predation by organisms which feed on $\underline{P}$. spatulata, or to environmental stress caused by increased temperatures during the summer months.

Other studies indicate that prey availability does not appear to be a factor in these cases, since Collembola populations do not significantly decrease after clearcutting (Huhta et al 1967, Huhta et al 1971). Huhta (1971) attributed predatory spider decreases in population to high temperatures during summer months, not to predation. If this is the case, nymph populations, which are often found deeper in the soil horizon than adults (Mitcheli 1978), may have been able to avoid temperature stresses by virtue of their microhabitat, and consequently survived in higher numbers.

Figure 14 illustrates the densities of the predatory gamasid genus Gamasellus for the five sampling periods. The clearcut levels were significantly lower $(\alpha=0.05)$ than the control levels after clearcutting. Figures 15 and 16 illustrate the adult and nymphal densities in the control and clearcut, respectively. Both nymph and adult densities in the control decreased dramatically by July. By March of the following year, control adults had returned to previous years' levels; the nymphs were lower than the previous year. In the clearcut, adult and nymph levels in March 1979 were significantly lower $(\alpha=0.05)$ than the previous 


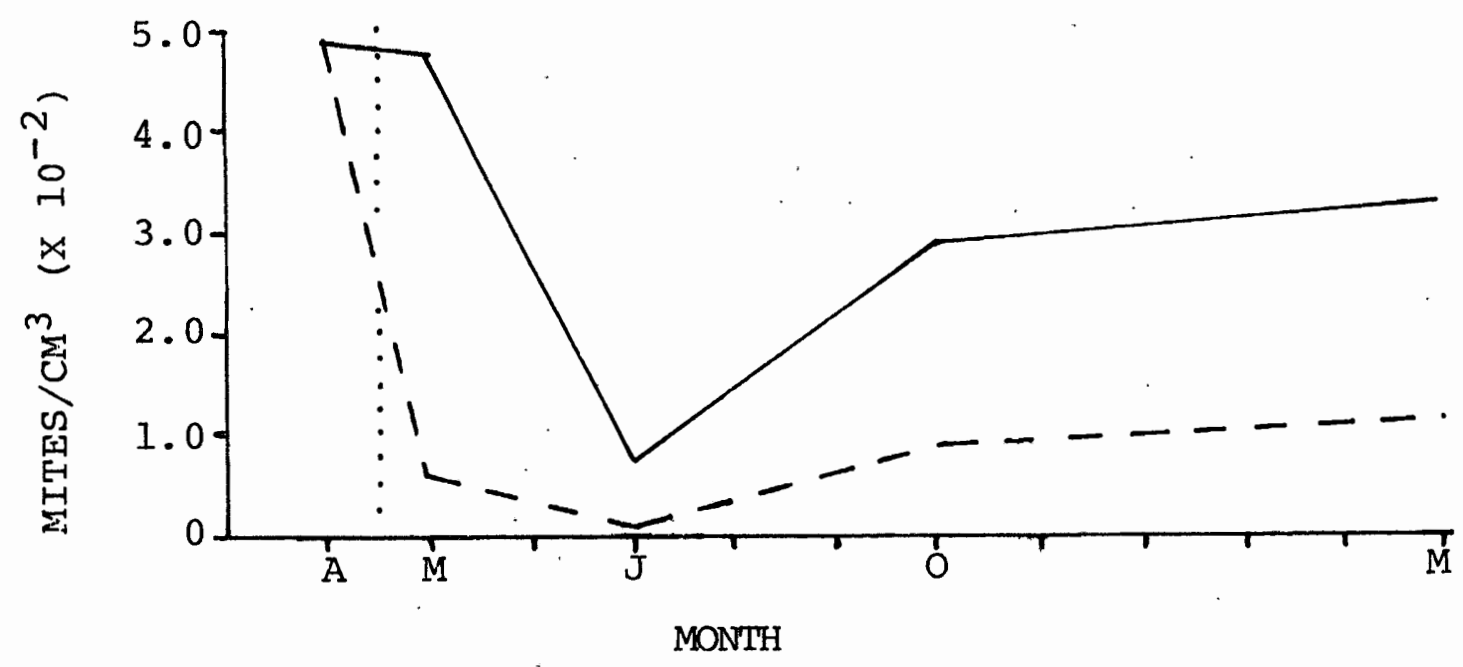

Figure 14. Changes in density of the predatory gamasid genus Gamasellus during the first year after clearcutting. Graph descriptions as in Figure 5.

year's levels, and only the nymphs appeared to be increasing in density.

Although the gamasellid and parholaspellid genera are found in the same cohort, they dia not behave similarly in

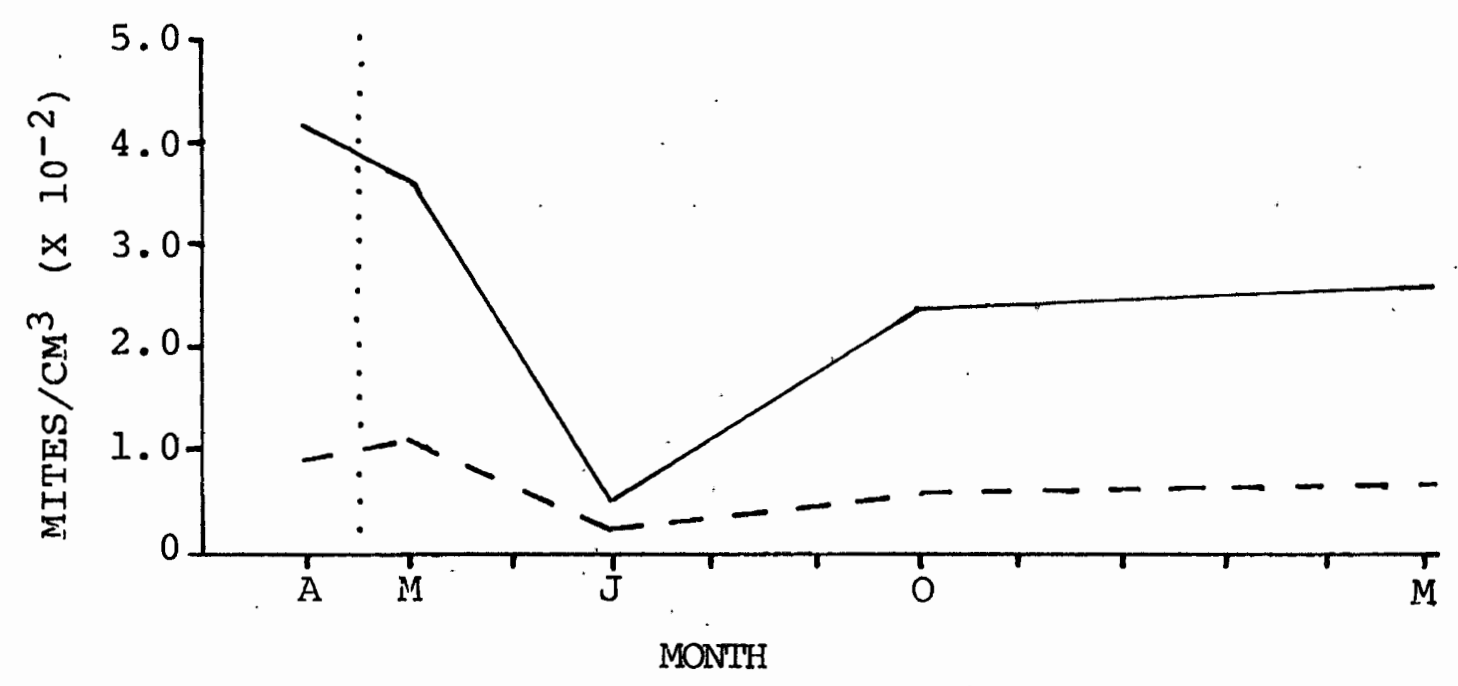

Figure 15. Changes in mean control densities of adult and nymphal Gamasellus during the first year after clearcuting. Graph description as in Figure 12. 


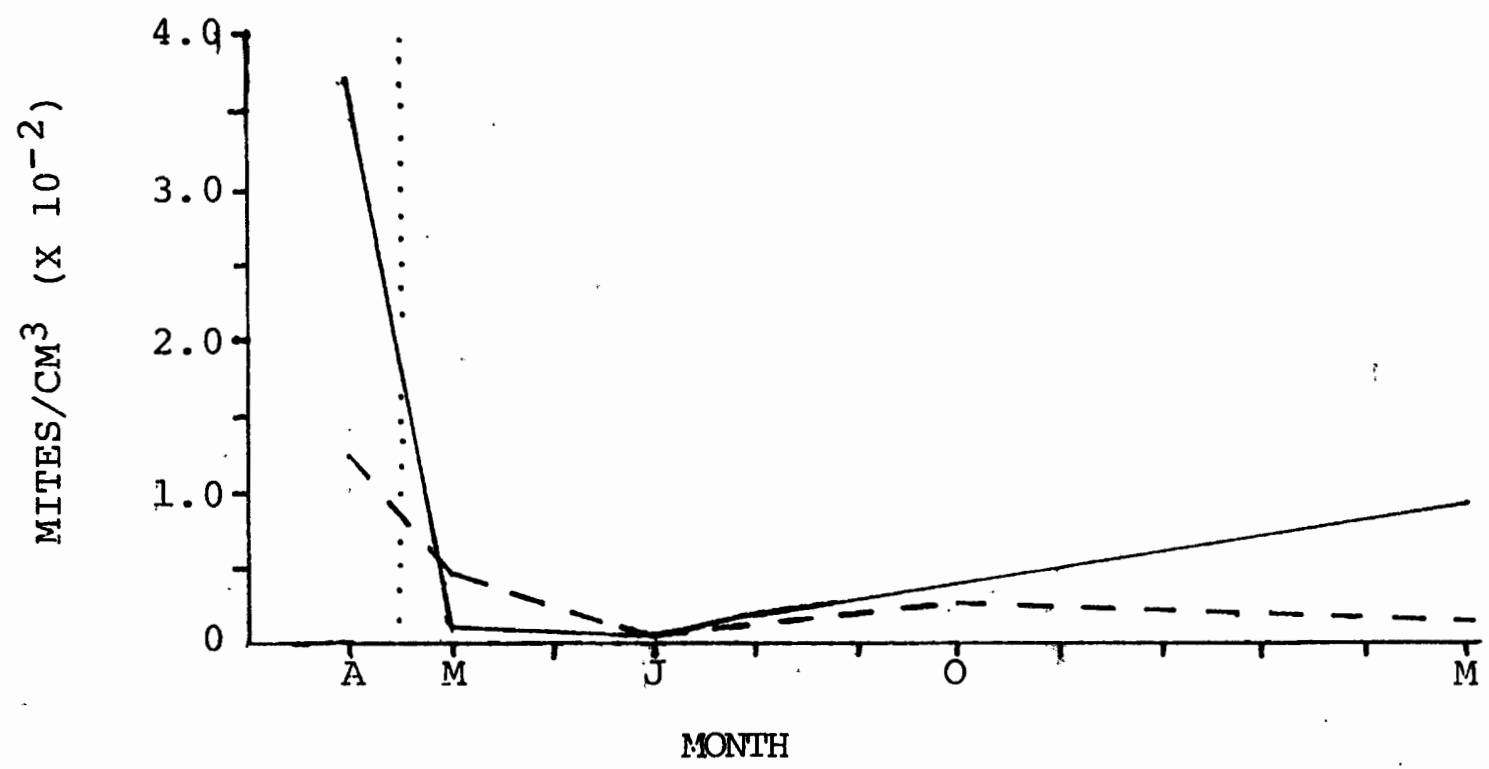

Figure 16. Changes in mean clearcut densities of adult and nymphal Gamasellus during the first year after clearcutting. Graph description as in Figure 12.

the control and clearcut. The total density of P. spatulata showed a decreasing trend in density after one year, but the Gamasellus species were increasing. Immature and adult stages of the two genera also behaved differently. In the controls, the nymphs of the gamasellid genus reacted unfavorably to summer seasonal affects, unlike the parholaspelid genus. Clearcut nymph densities of both genera sharply decreased immediately after clearcutting; adults of both genera significantly decreased in densities by July, and did not recover in the following month to previous (April 1978) levels. It appeared that for Gamasellus; environmental stress imposed by high summer soil temperatures prevented a recovery of adult populations. 
Vertical Migration

The macrophytophagous and microphytophagous mites studied showed no significant differences in vertical distribution between clearcut and controls after clearcutting. There were also no significant differences in Nicoletiella, a predatory genus. Significant differences $(\alpha=0.01)$ appeared when nymphal and adult stages were analyzed in the predatory mites Parholaspella spatulata and Gamasellus. The source of variation of these differences appeared between the control and experimental populations within adult and within juvenile populations. There were no significant differences however:between the top and bottom samples overall, nor between the juvenile and adult densities within the top and bottom samples.

Caution must be exercised in drawing conclusions from these results, however. The top samples were $6 \mathrm{~cm}$ deep and would not detect migrations of less than $6 \mathrm{~cm}$, as may more likely occur (Mitchell 1978). Therefore vertical migration may have been detected had different sampling techniques been used. Vlug and Borden (1973) noted that there was no change in clearcut densities within the first $10 \mathrm{~cm}$ of soil horizons, but rather that densities decreased in all layers.

Soil Compaction and Scarification

After clearcutting, approximately 55\% of the logged site was scarified and/or compacted by heavy machinery. The 
soil samples from these areas were sandy to gravelly, high in mineral content, and low in organic matter. Approximately $5 \%$ of the site was relatively undisturbed, similar to the control except for increased insolation. The remaining $40 \%$ of the area contained added debris, such as sawdust, chips, fallen branches, etc., which were a result of the clearcutting operations.

Soil compaction and scarification (i.e., removal of the organic layers from the soil) which result from tractor logging and skid roads formed during clearcutting operations may have biological implications. Microarthropods generally occupy small spaces between soil particles in the surface layers, and the diameter of the pore spaces may be limiting to their distribution (Wallwork 1970). Steinbrenner and Gessel (1955) found a 10\% reduction of macropore space in soils compacted by tractor logging, and a 53\% reduction in pore space in tractor skid roads. The bulk density of soils compacted by tractor logging and skid roads increased $2.4 \%$ and $15 \%$, respectively.

Macropore space allows ready movement of air and percolating water. Soil compaction may reduce microbial activity by impeding aeration and allowing carbon dioxide concentrations to increase (Bollen 1974). Since bacteria and fungi are the food source of many soil mites, this effect may have implications for their survival.

Organic matter is important in maintaining large 
macropore spaces (Buckman and Brady 1969); therefore scarification of soil can also result in loss of larger pore sizes, and to the effects mentioned above.

Steinbrenner and Gessel (1955) found a permeability rate decrease of $35 \%$ resulting from tractor logging, and a $93 \%$ decrease in tractor skid roads. Dyrness et al (1957) found lowered moisture equivalents and percent aggregations in clearcut soils, but these were not significant; he attributed the reductions to structural breakdown due to compaction. Isaac and Hopkins (1937) noted that duff has a very high water-holding capacity. Since competition for water may be limiting to soil microbes (Bollen 1974), these effects may result in less food for microphytophagous acari in scarified areas. However, Griffin (1972) said that since the volume of water necessary for microbial activity is very small, its significance is probably correlated with other properties, such as aeration. Williams (1963) found that moisture is important in fungal distribution in a podsol soil, and that colonization of mineral soil is partly dependent on particle size; colonization of mineral soil is less than that of organic matter. These findings also indicate that compaction and scarification have biological implications for macrophytophages and microphytophages.

\section{Temperature}

Analysis shows that soil temperatures at $13 \mathrm{~cm}$ in 
depth were not significantly different in the control and clearcut sites overall, but that there were highly significant $(\alpha=0.01)$ differences among sampling months within treatments. Figure 17 shows that in May and July, significantly higher $(\propto=0.05)$ soil temperatures occurred in the clearcut than in the control. No differences appear in October and March. The same results occur for the litter temperatures. The air temperatures were significantly different for the control and clearcut in all four months after logging; Figure 17 shows that the air temperature was lower in the control during May and July; and higher in the controls during October and March. The same pattern, not always statistically significant, occurred for the soil and litter temperatures.

U.S. Weather Bureau data for Cougar, Washington (elevation 203 meters) for the week preceding each sample date, and corrected for elevation by the environmental temperature lapse rate of 6.4 degrees Centigrade per 1000 meters (Strahler 1975) showed that the average air temperature prior to April 16, 1978 was $9.7^{\circ} \mathrm{C}$ maximum and $-0.8^{\circ} \mathrm{C}$ minimum; prior to May 20,1978 was $12.7^{\circ} \mathrm{C}$ maximum and $2.7^{\circ} \mathrm{C}$ minimum; prior to July 29,1978 was $24.2^{\circ} \mathrm{C}$ maximum and $9.7^{\circ} \mathrm{C}$ minimum; prior to October 7,1978 was $19.7^{\circ} \mathrm{C}$ maximum and $5.2^{\circ} \mathrm{C}$ minimum; and prior to March 29, 1979 was $13.7^{\circ} \mathrm{C}$ maximum and $-1.8^{\circ} \mathrm{C}$ minimum. Monthly temperatures were normal prior to each of the sampling dates. See Appendix D. 

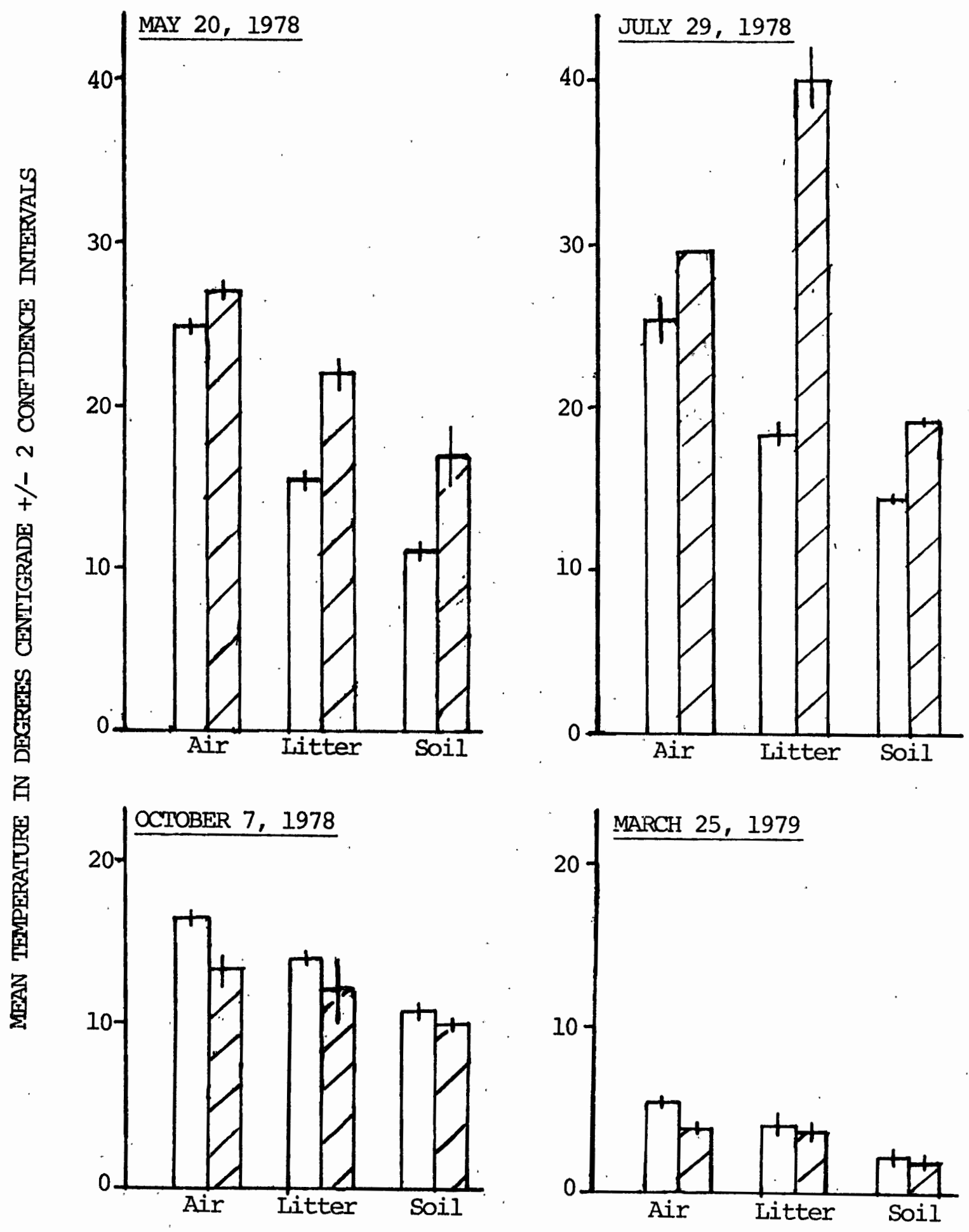

Figure 17. Mean temperatures in the controls (white bars) and clearcuts (hatched bars) in the four sampling months following clearcutting. April 1978 (pre-logging) temperatures were comparable to the March 1979 temperatures. 
Vegetation can affect soil temperatures by decreasing heat inflow through shading, preventing radiation of heat at night, and hindering air turbulence at the soil surface. clearcutting, by destroying the vegetative overstory, induces greater daily temperature fluctuations and seasonall extremes than in vegetated areas, and subjects the surface layers to drying by wind as well as by increasing temperatures (Huhta et al 1967, Buckman and Brady 1969).

Wallwork (1959, 1960) examined temperature tolerance for various oribatid mites in the laboratory and field. The upper tolerance was $30-32^{\circ} \mathrm{C}$, the tolerable range. was $16-28^{\circ} \mathrm{C}$, and the preferred range was $21-26^{\circ} \mathrm{C}$ for the species observed. He noted that there was a greater tolerance for relatively cold temperatures than relatively warm ones, and mortality was observed at temperatures starting at $30^{\circ} \mathrm{C}$. The U.S. Weather Bureau data indicates that mortality-inducing litter temperatures probably existed for at least one week in July, 1978.

Griffin (1972), commenting on microbial activity, noted that there is no support for the assumption that temperature fluctuation per se affects activity, but that growth is deterred some time after maximum temperatures are reached. Bollen (1974) correlated soil temperatures with moisture, stating that in the Pacific Northwest high summer seasonal temperatures and low summer and fall precipitation are the major limiting factors for microbes. In winter, 
microbes are not active and are limited by low temperatures, not by moisture, unless it is excessive.

The data in this study (Figure 17) indicate that temperature extremes on the soil surface are greatest in the July samples, when temperatures of $40^{\circ} \mathrm{C}$ were measured in the clearcut, compared to $18.5^{\circ} \mathrm{C}$ in the control. Mortality would be expected then in the clearcut sites. Also, microbial activity would be reduced at these temperatures, resulting in lowered food supplies for microphytophagous mites. Significant differences in temperature, although not as extreme as in July, were also observed in May. In the October and March samples, litter temperatures were not significantly different between the controls and clearcuts, and therefore were probably not important to difierences in densities at those times. Soil temperatures at $13 \mathrm{~cm}$ in depth were also significantly higher only in May and July.

\section{Moisture}

Soil moisture in March 1979 was significantly higher $(\alpha=0.01)$ in the controls than in the clearcuts, but the sites were not significantly different from each other in October, 1978.

U.S. Weather Bureau data for Cougar, Washington (see Appendix D) stated that the precipitation one week prior to April 16, 1978 totaled 4.1 cm; prior to May 20, 1978 totaled $4.3 \mathrm{~cm} ;$ prior to July 29, 1978 totaled $0.33 \mathrm{~cm}$; prior to 
October 7, 1978 no precipitation fell; and prior to March 25, 1979 totaled $0.03 \mathrm{~cm}$. Monthly average precipitation in all cases was normal. There appears to be no correlation between the amount of precipitation and the monthly acari densities in the control or clearcut, based on this data. Increased insolation as a result of clearcutting changes moisture conditions of the soil. Some of these effects have been discussed previously. After clearcutting, tree and plant roots will no longer remove water from the soil, but evaporation will increase, unless prevented by a cover of felling residues.

Mitchell (1978) found that only acari inhabiting the fermentation and humus layers of the soil horizon show a positive correlation to moisture, and that litter inhabitants are not sensitive to moisture. Huhta (1971) found that moisture is not important for litter-dwelling spiders in clearcuts, but temperature is. Huhta et al (1967) found that oribatids react slowly to changes in moisture because their thick cuticle is resistant to desiccation; other mites, however, may be affected by abundant precipitation. Madge (1964) found that the higher the temperature, the higher the preferred relative humidity by soil acari, in laboratory experiments.

Excess moisture may be limiting to microbes by reducing oxygen concentrations in the soil pore spaces (Bollen 1974). Moreover, competition for water may be limiting to 
microbes in dry periods (Bollen 1974., Parkinson and Coups 1963), especially to bacteria and actinomycetes which are more sensitive to drought than are fungi (Steubing 1970). Most fungi are found in the litter and fermentation layers of the soil horizon (Parkinson and Coups 1963), and most bacteria are found in the fermentation layers (Bollen 1974). The distribution of fungi in the soil appears to depend on moisture, mineral grain size, and depth (Williams 1963). Buckman and Brady (1969) state that fungi and bacteria can use hygroscopic soil water, although sub-optimal1y. This supports Griffin's comment (1972) that the volume of water needed for microbial activity is so small that it, in itself, should not be limiting.

Vlug and Borden (1973), found no correlations with soil moisture and mite densities in a clearcut. Since soil moisture readings were not taken during every sampling month during this study, general conclusions cannot be drawn. However, the data for March 1979 and October 1978 and the U.S. Weather Bureau data, when compared to densities of the various mites studied, do not support the idea that moisture of itself is significant to the acari densities. This is in agreement with the findings of Vlug and Borden (1973) . 


\section{CONCLUSIONS}

Generally, soil acari densities decreased significantIy in the clearcut site almost immediately after the clearcutting operation occurred. Both control and clearcut densities decreased to very low levels by midsummer (July), and the clearcut densities were much lower than the control densities. By October, however, the control densities had recovered to higher densities than the clearcut. The lower summer densities occurring in the clearcut were attributed to the high temperatures of the litter horizon as a result of increased insolation after the cover story was removed. Wallwork $(1959,1960)$ found that temperatures in excess of $30^{\circ} \mathrm{C}$ induce mortality in soil acari; in this study, soil surface temperatures in excess of $40^{\circ} \mathrm{C}$ were recorded. Indirect effects of temperature on food may also be important for microphytophagous mites; although not measured in this study, food availability may have been significant.

Soil moisture did not show correlations with densities ties. Oribatid mites are heavily-sclerotized so that moisture may not be important to them, but mites less-sclerotized than oribatids (primarily in other sub-orders and juvenile stages) and those inhabiting lower horjzons may be affected by moisture changes (Mitchell 1978).

Food supplies were not measured directly, but were 
probably limited for all trophic levels. Macrophytophagous mites cannot utilize freshly-fallen litter, microphytophagous mites may have had food shortages due to physical effects on microbial activity, and predators may have been affected by decreases in populations in other organisms, including mites.

Pore spaces may have been important for larger mites, especially in areas which were scarified by heavy machinery. Mites live in existing pore spaces, so a reduction in pore space size could affect their survival.

When predatory mites were divided into juvenile and adult stadia and statistically analyzed, it appeared that adults were more affected by increased insolation and consequent higher temperatures than juveniles. This may be because nymphs often occupy lower soil horizons than the adults (Mitchell 1978), and so would escape the highest temperatures at the soil surface. The october juvenile densities of the clearcut were not as high as the control juvenile densities, and this would also have an impact on future generations; this was reflected in the March 1979 sample.

The results of this study differed in some respects from Huhta et al (1967), since the oribatid clearcut densities were not near as high as the control densities after one year, as was reported by them.

Vertical migration was not detected but that may have 
been due to technique. Vlug and Borden (1973) found no vertical migration in the first $10 \mathrm{~cm}$ after clearcutting. 


\section{BIBLIOGRAPHY}

Anscombe, F.J. 1949. The statistical analysis of insect counts based on the negative binomial distribution. Biometrics 5(2): 165-179.

Berthet, P. and G. Gerard. 1965. A statistical study of microdistribution of Oribatei (Acari). Part I: The distribution pattern. Oikios 16: 214-227.

Bollen, W.B. 1974. Soil Microbes. Pages Bl-B4l in O.P. Cramer, editor. Environmental Effects of Forest Residue Management in the Pacific Northwest: A State-of-Knowledge Compendium. USDA Forest Service General Technical Report PNW-24, Pacific Northwest Forest and Range Experimental Station.

Buckman, H.O. and N.C. Brady. 1969. The Nature and Properties of Soils. The Mackillan Company, New York. $653 \mathrm{pp}$.

Cornaby, B.W. 1977. Saprophagous organisms and problems in applied resource partitioning. Pages 96-100 in W.J. Mattson, editor. The Role of Arthropods in Forest Ecosystems. Springer-Verlag, New York.

Crossley, D.A., Jr. 1977a. Oribatid mites and nutrient cycling. Pages 71-85 in D.L. Dindal, editor. Biology of Oribatid Mites. State University of New York, College of Environmental Science and Forestry, Syracuse, New York.

- 1977b. The roles of terrestrial saprophagous arthropods in forest soils: current status of concepts. In W.J. Mattson, ed. The Role of Arthropods in Forest Ecosytems. Springer-Verlag, New York.

Duncan, S.H. and E.C. Steinbrenner. 1973. Soil Survey of the St. Helens Tree Farm. Weyerhaeuser Company, Tacoma, Washington.

Dyrness, C.T., C.T. Youngberg, and R.H. Ruth. 1957, Some effects of logging and slash burning on physical soil properties in the Corvallis watershed. USDA Forest Service Research Paper \#9, Pacific Northwest Forest and Range Experimental Station.

Edwards, C.A. and G.W. Heath. 1963. The role of soil animals in breakdown of leaf material. Pages 76-84 in J. Doeksen and J. van der Drift, editors. Soil Organisms: Proceedings of the Colloguim on Soil Fauna, Soil Microfauna, and their Relationships. North-Holland Publishing Company, Amsterdam. 
Engelmann, M.D. 1961. The role of soil arthropods in the energetics of an old field community. Ecological Monographs 31: 221-238.

Francke-Grosmann, H. 1963. Some new aspects of forest entomology. Ann. Rev. Entom. 8: 415-438.

Franklin, J.F. and C.T. Dyrness. 1973. Natural Vegetation of Oregon and Washington. USDA Forest Service General Technical Report \#8, Pacific Northwest Forest and Range Experimental Station.

Gerard, G. and P. Berthet. 1966. A statistical study of microdistribution of Oribatei (Acari). Part II: The transformation of the data. Oikos 17: 142-149.

Ghilarov, M.S. 1963. On the interrelationships between soil-dwelling invertebrates and soil microorganisms. Pages 255-259 in J. Doeksen and J. van der Drift, eds. Soil Orgänisms. North-Holland Publishing Company, Amsterdam.

- 1971. Invertebrates which destroy the forest litter and ways to raise their activity. Pages 433-442 in Productivity of Forest Ecosystems: Proceedings of the Brussels Symposium, 1969. UNESCO.

Gist, C.S. and D.A. Crossley, Jr. 1975. The litter arthropod community in a southern Appalachian hardwood forest: numbers, biomass, and mineral element content. American Midiand Naturalist 93: 107-122.

Gray, T.R.G. and S.T. Williams. 1971. Soil Micro-Organisms. Oliver and Boyd, Edinburgh.

Griffin; D.M. 1972. Ecology of Soil Fungi. Chapman and Hall, London. $193 \mathrm{pp}$.

Hartenstein, R. 1961. On the distribution of forest soil microarthropods and their fit to 'contagious' distribution functions. Ecology 42: 190-194.

Hinshelwood, C. 1951. Decline and death of bacterial populations. Nature 167: 666-669.

Huhta, V. 1971. Succession in the spider communities of the forest floor after clear-cutting and prescribed burning. Ann. Zool. Fennici $8(4)$ : 483-542.

- 1976. Effects of clearcutting on numbers, biomass, and community respiration of soil invertebrates. Ann. Zool. Fennici 13: 63-80.

E. Karppinen, M. Nurminen, and A. Valpas. 1967. Effect of silvicultural practices upon arthropod, annelid, and nematode populations in coniferous forest sóil. Ann. Zoal. Fennici 4: 87145. 
M. Nurminen, and A. Valpas. 1969. Further notes on the effect of silvicultural practices upon fauna of coniferous forest soil. Ann. Zool. Fennici 6: 327-334.

Isaac, L.A. and H.G. Hopkins. 1937. The forest soil of the Douglas Fir region, and changes wrought upon it by logging and slash burning. Ecology 8(2): 264-279.

Jacot, A.P. 1939. Reduction of spruce and fir litter by minute animals. Journal of Forestry 37: 858-860.

Krantz, G.W. 1978. A Manual of Acarology. Oregon State University Book Stores, Inc. Corvallis, Oregon. 509 pp.

Kurcheva, G.F. 1960. The role of invertebrates in the decomposition of oak leaf litter. Pocroredenie 4: 16-23.

Luxton, M. 1972. Studies on the oribatid mites of a Danish beech wood soil. I. Nutritional biology. Pedobiologia 12: 434-463.

MacFadyen, A. 1961. Metabolism of soil invertebrates in relation to soil fertility. Ann. Appl. Biology 49: 215-218.

- 1962. Soil arthropod sampling. Adv. Ecol. Research 1: $1-34$.

1963. The contribution of the microfauna to total soil metabolism. Pages 3-17 in J. Doeksen and J. van der Drift, eds. Soil Organisms. North-Holland Publishing Co., Amsterdam.

- 1968. The measurement of climate in studies of soil and litter animals. Pages 59-67 in R. Wadsworth, editor. The Measurement of Environmental Factors in Terrestrial Ecology. Oxford, Edinburgh.

Madge, D.S. 1964. The humidity reactions of oribatid mites. Acarologia 6: 566-594. tain other species of oribatid mites in controlled temperature gradients. Acarologia 7: 389-406.

McBrayer, J.F. 1973. Exploitation of deciduous leaf litter by Apheloria montana (Diplopoda: Eurydesmidae). Pedobiologia 13: $\frac{\text { 90-98. }}{90}$

Mitchell, M. 1978. Vertical and horizontal distributions of oribatid mites (Acari: Cryptostigmata) in an aspen woodland soil. Ecology $59(3):$ 516-525. 
Mitchell, R.G. and C. Sartwel.1. 1974. Insects and other arthropods. Pages Rl-R22 in O.P. Cramer, ed. Environmental Effects of Forest Residue Management in the Pacific Northwest: USDA-FS Gen. Tech. Report PNW-24, Pacific Northwest Forest and Range Experimental Station.

Moore, D.G. and L.A. Norris. 1974. Soil processes and introduced chemicals. Pages Cl-C33 in O.P. Cramer, ed. Environmental Effects of Forest Residues Management in the Pacific Northwest. USDA-FS Gen. Tech. Report PNW-24, Pacific Northiwest Forest and Range Experimental Station.

Moritz, V.M. 1965. Untersuchungen über den Einfluss von Kahlschlagmassnahmen auf die zusanmensetzung von Hormil bengemeinschaften (Acari: Oribatei) norddeutscher Laub- und Ki efernmischwalder. Pedobiologia 5: 55-101.

Parkinson, D. and E. Coups. 1963. Microbial activity in a podzol. Pages 158-166 in J. Doeksen and J. van der Drift, eds. Soil Organisms. North-Holland Publishing Company, Amsterdam.

Smith, D. 1962. The Practice of Silviculture. John Wiley and Sons, Inc., New York. 758 pp.

Sokal, R.R. and F.J. Rohlf. 1969. Biometry: The Principles and Practice of Statistics in Biological Research. W.H. Freeman and Company, San Francisco. 776 pp.

Sørensen, T. 1948. A method of establishing groups of equal amplitude in plant sociology based on the similarity of species content and its application to analyses of the vegetation on Danish commons. Biol. Skr. 5: 1-34.

Steinbrenner, E.C. and S.P. Gessel. 1955. The effect of tractor logging on physical properties of some forest soils in southwestern Washington. Soil Sci. Soc. Amer. Proc. 19: 372-376.

Steubing, L. 1970. Soil flora: Studies of the number and activity of microorganisms in woodland soils. Pages 131-146 in D.E. Reichle, editor. Analysis of Temperate Forest Ecosystems. Springer, New York.

Strahler, A.N. 1975. Physical Geography. John Wiley and Sons, Inc., New York. $643 \mathrm{pp}$.

Szujecki, A. 1971. The effect of clearcutting upon the cormunity of litter-inhabiting staphylinids (Coleoptera: Staphylinidae) in fresh pine forests. Folia Forestalia Polonieá, Ser. A. 18: 5-45. 
1972. Impact of clearcutting on the soil entomofauna. Pages 4305-4309 in Proceedings, World Forestry Congress.

Buenos Aires, 7th Congress.

Vitousek, P.M., J.R. Gosz, C.C Grier, J.M. Melillo, W.A. Reiners, and R.I. Todd. 1979. Nitrate losses from disturbed ecosystems. Science 204: 469-474.

Vlug, H. and J. Borden. 1973. Soil acari and collembola populátions affected by logging and slash burning in a coastal British Columbia coniferous forest. Environ. Entom. 3(6): 1016-1023.

Wallwork, J.A. 1958. Notes on the feeding behaviour of some forest soil acarina. Oikos 9: 260-271.

- 1959. The distribution and dynamics of some forest soil mites. Ecology 40: 557-563.

- 1960. Observations on the behaviour of some oribatid mites in experimentally-controlled temperature gradients. Proc. Zool. Soc. London. 135: 619-629. 283 pp.

- 1976. The Distribution and Diversity of Soil Fauna. Academic Press, London. 355 pp.

Williams, S.T. 1963. The distribution of fungi in the horizons of a podsolized soil. Pages 158-166 in J. Doeksen and J. van der Drift, eds. Soil Organisms. North-Holland Publishing Co., Amsterdam.

Witkamp, M. 1960. Seasonal fluctuations of the fungus flora in mull and mor of an oak forest. Meded Inst. toegep. biol. Onderz. Nat. 46 (Arnhem).

$\therefore$ and D.A. Crossley, Jr. 1966. The role of arthropods and microflora in breakdown of white oak litter. Pedobiologia 6: 293-303. 
APPENDIX A

HABITAT DATA SHEET

WASHINGTON, COWLITZ COUNTY, WEYERHAEUSER TREE FARM KALAMA RIVER DISTRICT

T7N-R3E; Section 13 Elevation ca $731.5 \mathrm{~m} \mathrm{~ms} 1$

Date.

Time.

Collection Site: Plot \# ........ Sample \# ....... Treated ............... Untreated ...........

Habitat $\ldots \ldots \ldots \ldots \ldots \ldots \ldots \ldots \ldots \ldots \ldots \ldots \ldots \ldots$

Berlese.$\ldots \ldots \ldots \ldots \ldots \ldots \ldots \ldots \ldots \ldots \ldots \ldots \ldots \ldots$

Weather

Air Temp $(61 \mathrm{~cm})$...........Soil Temp (13 cm)......

Litter Temp $. . . \ldots \ldots \ldots . .$. Mineral Layer $. . . \ldots .$. Col lected by S.E. Orlaske SAMPLE NO. SO- 


\section{APPENDIX B}

CLASSIFICATION OF ACARI, OPILIONES, AND ARANEIDA OCCURRING IN SAMPIES

\section{ACARI}

Order Parasitiformes

Suborder Gamasida

Supercohort Monogynaspides

Cohort Gamasina

Superfamily Parasitoidea

Family Veigaiidae

Veigaia sp.

Superfamily Rhodacaroidea

Family Ologamasidae Gamasellus sp. Gamasiphis sp.

Superfamily Ascoidea

Family Zerconidae Microzercon sp. Macrozercon sp.

Superfamil Eviphidoidea

Family Parholaspellidae Parholaspella spatulata Krantz

Family Pachylaelapidae

Cohort Uropodina Pachylaelaps sp.

Superfamily Polyaspidoidea

Family Polyaspididae Polyaspinus $n r$. higginsi Trachytes sp. A Trachytes sp. B

Order Acariformes

Suborder Actinedida

Supercohort Promatides

Cohort Iabidstammatina

Superfamily Labidostommatoidea

Family Labidostommatidae Nicoletiella sp.

Cohort Eupodina

Superfamily Eupodoidea

Family Eupodidae

Eupodes Sp.

Cocceupodes sp. 


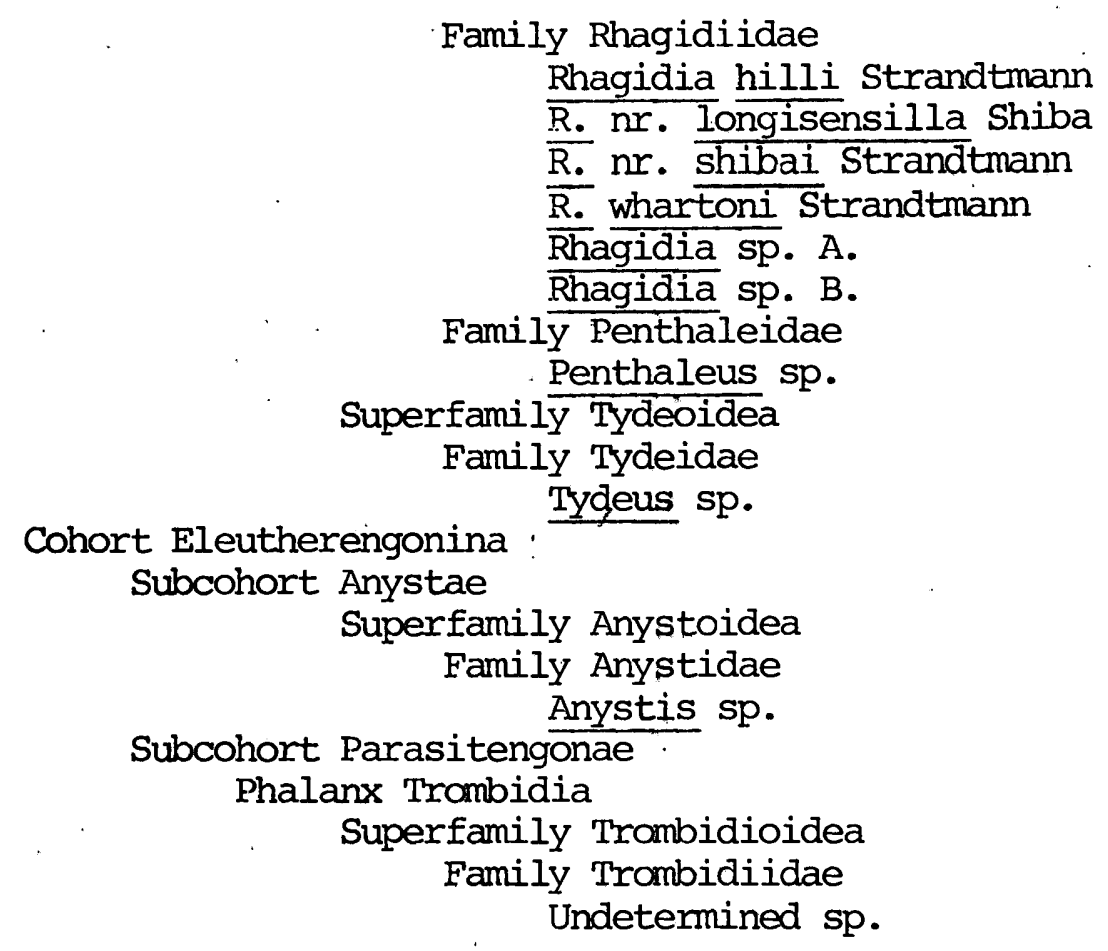

Suborder Oribatida

Supercohort Macropylides

Cohort Ptyctimina

Superfamily Phthiracaroidea

Family Phthiracaridae Phthiracarus sp. Superfamily Euphthiracaroidea

Family Oribotritiidae Oribotritia sp. Protoribotritia sp.

Family Euphthiracaridae Euphthiracarus sp.

Cohort Holonotina

E. tanythrix Walker

Superfamily Collohmannoidea

Family Nothridae Nothrus sp. nr. biciliatus

Family Camisssidae

Supercohort. Brachypylides Camisia sp. nr. segnis

Cohort Apterogasterina

Subcohort Polytrichae

Superfamily Nanhermannioidea

Family Nanhermanniidae

Nanhermannia sp.

Superfamily Hermannielloidea

Family Hermanniellidae

Hermanniella sp. 
Subcohort Oligotrichae

Superfamily Cepheoidea

Family Cepheidae

Eupterotegaeus sp.

Sphodrocepheus anthelionus

Woolley \& Higgins

Superfamily Carabodoidea

Family Carabodidae

Carabodes sp.

Superfamily Eremaeoidea

Family Eremaeidae

Eremaeus sp.

Superfamily Bellboidea

Family Damaeidae

Damaeus sp.

Superfamily Otócepheoidea

Family Oppiidae

Oppiella nova (Oudemans)

Superfamily Liacaroidea

Family Liacaridae

Liacarus sp.

L. bidentatus Ewing

Family Metrioppiidae

Ceratoppia sp.

Paenoppia sp.

Famil Astegistidae

Cultroribula ? trifurcata

Cohort Pterogasterina Jacot

Superfamily Pelopoidea

Family Pelopidae

Eupelops sp.

Superfamily Galumnoidea

Family Galumnidae

? genus (immature)

Superfamily Oribatelloidea

Family Oribatellidae

? genus (immature)

Family Achipteriidae

Anachipteria sp. (imm.)

Superfamily Oribatuloidea

Family Oribatulidae

Oribatula sp.

Scheloribates sp.

Family Suctobelbidae

Allosuctobellba sp. nr. obtusa (Jacot) 
II. OPIIIONES

Suborder Cyphophthalmi

Family Sironidae

Siro acaroides (Ewing)

Suborder Ianiatores

Family Triaenonychidae

Paranonychus brunneus (Banks)

III. ARANEIDA

Suborder Mygalamorphae

Family Mecicobothriidae

Hexura picea (Simon)

Suborder Araneomarphae

Family Telemidae

Usofila pacifica (Banks)

Family Thamisidae

Xysticus pretiosus Gertsch

Family Agelenidae

Family Theridiidae

Cybaeus sp. (indet. juv.)

Theridion sexpunctatum Emerton

Family Erigonidae

Symmigma minimum (Emerton)

Scironis sima (Chamberlin)

Ceratinops inflata Emerton

1 indet. sp. (juv.) 


\title{
APPENDIX C
}

\author{
TABULATION OF DATA
}

PTYCTIMINID MITES (SUBORDER ORIBATIDA)

$$
\begin{array}{lllll}
4 / 16 / 78 & 5 / 20 / 78 & 7 / 29 / 78 & 10 / 7 / 78 & 3 / 25 / 79
\end{array}
$$

Control

$\begin{array}{llllll}\text { Mean, } 4 \text { sites; X 10-2 } & 2.16 & 4.410 & 1.429 & 1.750 & 2.996 \\ \text { Variance, X 10-5 } & 7.686 & 2.692 & 5.292 & 0.853 & 3.284\end{array}$

Clearcut

$\begin{array}{llllll}\text { Mean, } 4 \text { sites, } \times 10^{-2} & 1.821 & 1.036 & 0.093 & 0.271 & 0.444 \\ \text { Variance, } \times 10^{-5} & 7.320 & 1.865 & 0.033 & 0.130 & 0.452\end{array}$

Analysis of Variance

df MS $\quad$ Fs Level

Between clearcut and control treatment 1 Among days within

$$
\text { treatments }
$$

Among sites within days

Within sites

1

6

24

96

Between bottom and top levels

Between clearcut and

1 control within levels Among days within sites
$2.212 \times 10^{-4}$

9.2821

0.05

$2.384 \times 10^{-5}$

1.9273

N.S.

$1.237 \times 10^{-5}$

$1.772 \times 10^{-5}$

0.6979

N.S.
$2.507 \times 10^{-5}$

$2.472 \times 10^{-4}$

$8.120 \times 10^{-5}$
0.1014 N.S.

3.0443 N.S. 
HERMANNIELLA SP. (SUBORDER ORIBATIDA)

$$
\begin{array}{lllll}
4 / 16 / 78 & 5 / 20 / 78 & 7 / 29 / 78 & 10 / 7 / 78 & 3 / 25 / 79
\end{array}
$$

Control

Mean, 4 sites, $\times 10^{-2}$

Variance, $\times 10^{-5}$
3.450

8.336

3.850

7.990

2.720

5.720

3.560

6.473

0.849

Clearcut
Mean, 4 sites; $x 10^{-2}$
2.959
4.640
0.395
1.680
0.296
Variance, $\times 10^{-5}$
6.452
0.233
$0.006 \quad i .806$
0.120

Analysis of Variance

df . MS Fs Level

Between clearcut and control treatment Among days within treatments

Among sites within days

Within sites

$\begin{array}{rrrr}1 & 2.637 \times 10^{-5} & 6.1889 & 0.05 \\ 6 & 4.264 \times 10^{-6} & 0.6838 & \text { N.S. } \\ 24 & 6.230 \times 10^{-6} & 1.1796 & \text { N.S. } \\ 96 & 5.282 \times 10^{-6} & & \end{array}$

Between top and bottom levels 1 $1.221 \times 10^{-5}$ 0.4071 N.S. Between treatments within levels Among days within sites $2.999 \times 10^{-5}$ $8.748 \times 10^{-6}$

3.4289 N.S. 2 
TRACHYTES SP. (SUBORDER GAMASIDA)

\section{$\begin{array}{lllll}4 / 16 / 78 & 5 / 20 / 78 & 7 / 29 / 78 & 10 / 7 / 78 & 3 / 25 / 79\end{array}$}

Control

Mean, 4 sites, $X 10^{-3}$

Variance, $x$ 10-5

6.40

6.657

3.945

9.860

7.889

$3.145 \quad 1.451$

0.027

0.117

0.136 .

Clearcut

Mean, 4 sites, $x 10^{-3}$

Variance, $\times 10^{-5}$

$5.671 \cdot 1.480$

$1.256 \cdots 0.292$

0.000

0.986

0.000

0.000

0.006

0.000

Analysis of Variance

df

MS

F s

Level

Between clearcut and

control treatment 1

Among days within

treatments

Among sites within days

Within sites

$1.573 \times 10^{-5}$

25.1302

0.01

6

$6.259 \times 10^{-7}$

0.6513

N.S.

24

96

$9.761 \times 10^{-7}$

$3.687 \times 10^{-6}$

Between top and bottom levels

Between treatments within levels

Among days within sites
1

$4.503 \times 10^{-6}$

0.3057

N.S.

2

4
$1.473 \times 10^{-6}$

$5.339 \times 10^{-6}$
0.2759

N.S. 
NANHERMANNIA SP. (SUBORDER ORIBATIDA)

$$
\begin{array}{lllll}
4 / 16 / 78 & 5 / 20 / 78 & 7 / 29 / 78 & 10 / 7 / 78 & 3 / 25 / 79
\end{array}
$$

Control

Proportion of. sites

having genus

$\begin{array}{lllll}1.00 & 1.00 & 0.93 & 1.00 & 0.93\end{array}$

Clearcut

Proportion of sites having genus

$1.00 \quad 0.88$

0.73

0.63

0.60

Analysis of Variance

df

MS

Fs

Level

Between clearcut and control treatment 1 Among days within treatments 6 $\begin{array}{lll}5913.0 & 20.51 & 0.01\end{array}$ Among sites within days

24

288.3

1.38

N.S.

208.6 
NICOLETIELTA SP. (SUBORDER ACTINEDIDA)

$$
\begin{array}{lllll}
4 / 16 / 78 & 5 / 20 / 78 & 7 / 29 / 78 & 10 / 7 / 78 & 3 / 25 / 79
\end{array}
$$

Control

Mean, 4 sites, $\times 10^{-3}$

Variance, $x 10^{-6}$
3.358

1.263
6.90

3.063
1.479
0.783

7.64

4.596
2.71

1.563

Clearcut
Mean; 4 sites, $\times 10^{-3}$
3.009
5.9
0.000
0.986
0.739
Variance, $x \cdot 10^{-7}$.
0.730
.3 .833
0.000
3.333
1.625

Analysis of Variance

df MS

Fs Level

Between clearcut and control treatment 1 Among days within treatments

6

$$
5.667 \times 10^{-6}
$$

6.245

0.05

Among sites within days

Within sites

$9.076 \times 10^{-7}$

$19.627 \quad 0.01$

24

96

$4.624 \times 10^{-8}$

$5.941 \times 10^{-7}$

0.078

0.01

Between top and bottom levels

1

$3.676 \times 10^{-6}$

$0.575 \quad$ N.S.

Between treatments within levels

Among days within sites

$6.395 \times 10^{-6}$

$2.654 \times 10^{-6}$

$2.410 \quad$ N.S. 
PARHOLASPETIA SPATUIAATA (SUBORDFR GNHASIDA)

Total densities (Nymphs + Adults)

$$
\begin{array}{lllll}
4 / 16 / 78 & 5 / 20 / 78 & 7 / 29 / 78 & 10 / 7 / 78 & 3 / 25 / 79
\end{array}
$$

Control

$\begin{array}{llllll}\text { Mean, } 4 \text { sites, } \times 10^{-2} & 1.55 & 1.75 & 1.61 & 1.25 & 0.388 \\ \text { Variance, X } 10^{-5} & 8.12 & 8.68 & 17.0 & 6.91 & 4.97\end{array}$

Clearcut

$\begin{array}{llllll}\text { Mean, } 4 \text { sites, } \times 10^{-2} & 1.42 & 0.369 & 0.364 & 0.647 & 0.197 \\ \text { Variance, } \times 10^{-5} & 3.90 & 1.95 & 3.43 & 4.86 & 0.869\end{array}$

Analysis of Variance

df MS Fs Level

Between clearcut and control treatment $I^{\prime} \quad 5.51 \times 10^{-4} \quad 20.792 \quad 0.01$ Among days within treatments

Among sites within days

Within sites 6

$2.65 \times 10^{-5}$

$3.014 \cdot 0.05$

24

96

$8.792 \times 10^{-6}$

$0.577 \quad$ N.S.

Adult densities

$$
\begin{array}{lllll}
4 / 16 / 78 & 5 / 20 / 78 & 7 / 29 / 78 & 10 / 7 / 78 & 3 / 25 / 79
\end{array}
$$

Control

Mean, 4 sites, $x 10^{-3}$ Variance, $x 10^{-5}$
6.16

2.43
5.18

0.849

0.863

0.115

0.925

3.02

$0.175 \quad 1.42$

Clearcut

$\begin{array}{llllll}\text { Mean, } 4 \text { sites, X } 10^{-3} & 6.53 & 1.29 & 0.000 & 0.493 & 0.431 \\ \text { Variance, X 10-5 } & 2.19 & 0.243 & - & 0.091 & 0.039\end{array}$


PARHOLASPEIIA SPATULATA, continued

Analysis of Variance

df MS , Fs Level

Between clearcut and

control treatment $1 \quad 2.262 \times 10^{-5} \quad 3.356 \ldots$ N.S.

Among days within

treatments

$6.74 \times 10^{-6} \quad 8.999 \quad 0.01$

Among sites within

days

6

$7.49 \times 10^{-7} \quad 7.133 \quad$ N.S.

Nymph densities

\section{$\begin{array}{lllll}4 / 16 / 78 & 5 / 20 / 78 & 7 / 29 / 78 & 10 / 7 / 78 & 3 / 25 / 79\end{array}$}

Control

Mean, 4 sites, $\mathrm{X} 10^{-2}$

0.934

1.232

1.527

1.158

0.586

Variance, $\times 10^{-4}$

0.065

2.38

2.72

2.42

0.141

Clearcut

Mean, 4 sites, $\times 10^{-2}$

Variance, $\times 10^{-5}$

$\begin{array}{lllll}0.767 & 0.240 & 0.364 & 0.598 & 0.154 \\ 0.235 & 4.76 & 3.43 & 2.26 & 2.399\end{array}$

Analysis of Variance

df MS Fs Level

Between clearcut and control treatment 1

$3.94 \times 10^{-4} \quad 15.183 \quad 0.01$

Among days within

treatments

Among sites within

days

Within sites

$13.94 \times 10^{-4}$

6

$2.595 \times 10^{-5}$

24

96

$6.638 \times 10^{-6}$

$1.194 \times 10^{-5}$

$3.910 \quad 0.01$

0.556 N.S. 
PARHOLASPELTA SPATULATA, continued

Analysis of Vertical Migration

df

MS

Fs

Level

Between top and

bottom levels

Between juvenile and

adults within

levels

Between treatments within stadia

Among days within

treatments

$1 \quad 1.446 \times 10^{-4} \quad 0.3479 \quad$ N.S.

$24.157 \times 10^{-4} \quad 1.8268$ N.S.

$4 \quad 2.275 \times 10^{-4} \quad 6.2216 \quad 0.01$

$24 \quad 3.657 \times 10^{-5}$ 
GAMASETLUS SP. (SUBORDER GAMASIDA)

Total densities (Nymphs + Adults)

$$
\begin{array}{lllll}
4 / 16 / 78 & 5 / 20 / 78 & 7 / 29 / 78 & 10 / 7 / 78 & 3 / 25 / 79
\end{array}
$$

Control

Mean, 4 sites, $x 10^{-2}$

Variance, $\times 10^{-4}$ $\begin{array}{ll}5.14 & 4.60 \\ 0.754 & 3.25\end{array}$

4.60
3.25

0.741

2.94

0.029

0.328

3.21

0.286

\section{Clearcut}

Mean, 4 sites, $x 10^{-2}$

Variance, $\times 10^{-5}$

$\begin{array}{ll}4.76 & 0.568 \\ 0.302 & 1.060\end{array}$

0.123

0.667

0.348

0.927

1.04

3.78

Analysis of Variance

df

MS

Fs

Level

Between clearcut and control treatment

Among days within treatments

Among sites within days

Within sites

$\begin{array}{rrrr}1 & 1.874 \times 10^{-4} & 7.744 & 0.05 \\ 6 & 2.419 \times 10^{-5} & 9.231 & 0.01 \\ & & & \\ 94 & 2.621 \times 10^{-6} & 0.8591 & \text { N.S. } \\ 96 & 3.051 \times 10^{-6} & & \end{array}$

Adult densities

\section{$\begin{array}{lllll}4 / 16 / 67 & 5 / 20 / 78 & 7 / 29 / 78 & 10 / 7 / 78 & 3 / 25 / 79\end{array}$}

Control
Mean, 4 sites, $x 10^{-2}$
0.97
1.24
0.320
0.715
0.841
Variance, $\times 10^{-5}$
0.079
0.288 .
0.089
2.094
0.422

Clearcut

Mean, 4 sites, $\times 10^{-2}$

1.200

2.799

0.444
1.328

0.049
0.097

0.247

0.148

Variance, $\times 10^{-}$

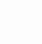


GAMASELIUS SP., continued

Analysis of Variance

df MS $\quad$ Fs $\quad$ Level

Between clearcut and control treatment Among days within treatments

Among sites within days

Within sites

$\begin{array}{rrrr}1 & 1.156 \times 10^{-5} & 7.285 & 0.05 \\ 6 & 5.639 \times 10^{-6} & 5.639 & 0.01 \\ 24 & 2.815 \times 10^{-7} & 0.660 & \text { N.S. } \\ 96 & 4.267 \times 10^{-7} & & \end{array}$

Nymph densities

\section{$\begin{array}{lllll}4 / 16 / 78 & 5 / 20 / 78 & 7 / 29 / 78 & 10 / 7 / 78 & 3 / 25 / 79\end{array}$}

Control

Mean, 4 sites, $x 10^{-2}$

4.17

3.33

0.419

.1 .998

2.18

Variance, $\times 10^{-4}$

0.915

3.60

0.015

0.413

0.642

Clearcut
Mean, 4 sites, $x 10^{-2}$
3.56
0.123
0.074
0.419
0.637
Variance, $\times 10^{-5}$
1.925
0.024
0.089
1.710
4.070

Analysis of Variance

df MS Fs Level

Between clearcut and control treatment Among days within treatments

Among sites within days

Within sites

$9.43 \times 10^{-5} \quad 6.564$

0.05

6

$1.437 \times 10^{-5}$

4.776

0.01

$3.008 \times 10^{-6}$

1.234

N.S. 
GAMASELIUS SP., continued

Analysis of Vertical Migration

df MS Fs Level

Between top and bottom levels Between stadia within levels Between treatments within stadia Among days within treatments

$1 \quad 1.596 \times 10^{-5} \quad 3.626 \quad$ N.S.

$24.402 \times 10^{-5} \quad 0.785 \quad$ N.S.

4

$5.61 \times 10^{-5} \quad 4.685 \quad 0.01$

$24 \quad 1.197 \times 10^{-5}$ 


\section{APPENDIX D}

UNITED STATES WEATHER BUREAU DATA FOR WEEK PRECEDING EACH SAMPLE DATE COUGAR, WASHINGTON ETEV. $203 \mathrm{~m}$

APRIL 16, 1978

11

12

13

14

15

16

Ave.

Temp. , ${ }^{\circ} \mathrm{C}$

Max.

Min.

11.7

15.6

7.8

8.9

14.4

13.2

Precip. ,cm

4.4

1.7

0.0

2.8

3.3

0.97

2.8

2.5

0.00

0.00

0.00

1.40

1.70

19

20

Ave.

Temp. , ${ }^{\circ} \mathrm{C}$

Max.

Min.

$15 \quad 16$

17

18

19

8.9

4.4

12.8

17.2

25.6

7.2

5.6

0.00

26.7

15.9

Precip., cm

3.30

0.91

0.08

0.00

10.6

5.8

JULY 29, 1978

24

25

26

27

28

29

Termp. , ${ }^{\circ} \mathrm{C}$

Max.

29.4

28.9

33.3

26.7

12.8

15.0

0.33

22.2

25.0

27.6

Precip. ,cm

0.00

0.00

12.2

11.1

13.0

OCTOBER 7, 1978

Temp. , ${ }^{\circ} \mathrm{C}$ Max. Min.

$$
2
$$

2

Precip.; cm

20.6

6.7

23.3

7.2

22.8

23.9

8.3

8.3

0.00

0.00

Ave.

MARCH 25, 1979

$$
20
$$

0.00

0.00

23.3
11.1

24.4

9.4

23.1

0.00

0.00

0.00

Ave.

Temp. , ${ }^{\circ} \mathrm{C}$

Max.

Min.

12.8

17.2

17.8

1.1

22

23

24

25

25

Ave.

Precip. , cm

1.7
0.00

0.00

0.00

16.7

1.7

20.6

1.7

0.00

0.00

16.7

0.6

17.0

1.4 